\title{
ROFRAQ: A statistics-based empirical method for assessing accident risk from rockfalls in quarries
}

\author{
L.R. Alejano , H.W. Stockhausen , E. Alonso , F.G. Bastante, P. Ramírez Oyanguren \\ Department of Natural Resources and Environmental Engineering, University of Vigo, Vigo, Spain \\ Repsol Gas, Madrid, Spain \\ Department of Mineral Resources Exploitations and Underground Works, Polytechnic University of Madrid, Madrid, Spain
}

\begin{abstract}
This paper describes an empirical method, called Rockfall Risk Assessment for Quarries (ROFRAQ), which assesses the risk associated with rockfalls in quarries. The method is based on a probabilistic approach that assumes that an accident occurs as a consequence of a sequence of events. This method has been applied to slopes in a number of quarries, and has proved useful in detecting troublesome slopes on the basis of empirical evidence. Thus far, it has been applied to around 100 slopes from various quarries of different rocks. These results show satisfactory agreement with results for empirical methods applied in the civil engineering field to highways and roads. The authors describe a case study of a granite aggregate quarry that highlights a number of issues in relation to practical application of the method.
\end{abstract}

Keywords: Rockfall; Risk assessment; Quarry slope design; Empirical methods; Mine safety

\section{Introduction}

Rockfall phenomena have been widely studied within the frame of population risks and civil engineering for mountain valleys, roads and highways. In the field of mining engineering research has concentrated on analyses of general slope stability, given the potential economic impact of this aspect of mining. However, rockfall phenomena have also been studied for open pit mines and quarries if not in such a detailed way. Rock mechanics applied to mining as pointed out by Hood and Brown - has over time come to focus on improving safety and productivity.

A number of authors have pointed out that rockfalls are responsible for around the same number of accidents and fatalities as general slope instability, and various data from Spanish quarries would seem to corroborate this assertion In a study of mining accidents in the province of Pontevedra, for example, 30 accidents involving fatalities or severe injuries were recorded over an 18-year period and of the five sloperelated accidents, three were associated with general slope instability, and two with rockfalls. Note that this cannot be considered an excessive number of slope-related accidents for the quarries studied, as many of these were ornamental granite quarries, which tend to have a lightly fractured rock mass consequently, relatively few blocks become detached and fall.

However, the situation is rather different for more heavily fractured rock masses. ANEFA (the Spanish Association of Aggregate Producers) reported that the most common single cause of fatalities in its quarries was rockfalls (representing over $20 \%$ of accidents), and it was, in fact, the high incidence of rockfall-related fatalities in Spain (35 in a 9-year period) that inspired this study (Fig. 1). In absolute terms, most of the accidents are caused by human error (falls and machinery-related accidents). Reducing the number of accidents requires greater emphasis to be placed on education and training so as to improve safety at work. However, rockfall accidents also need to be formally studied so as to devise suitable 
FATALITIES IN OPEN PIT AGGREGATE MINING IN SPAIN.

Form 1987 to 1995. Data reported by ANEFA (Spanish Association of Aggregate Producers)

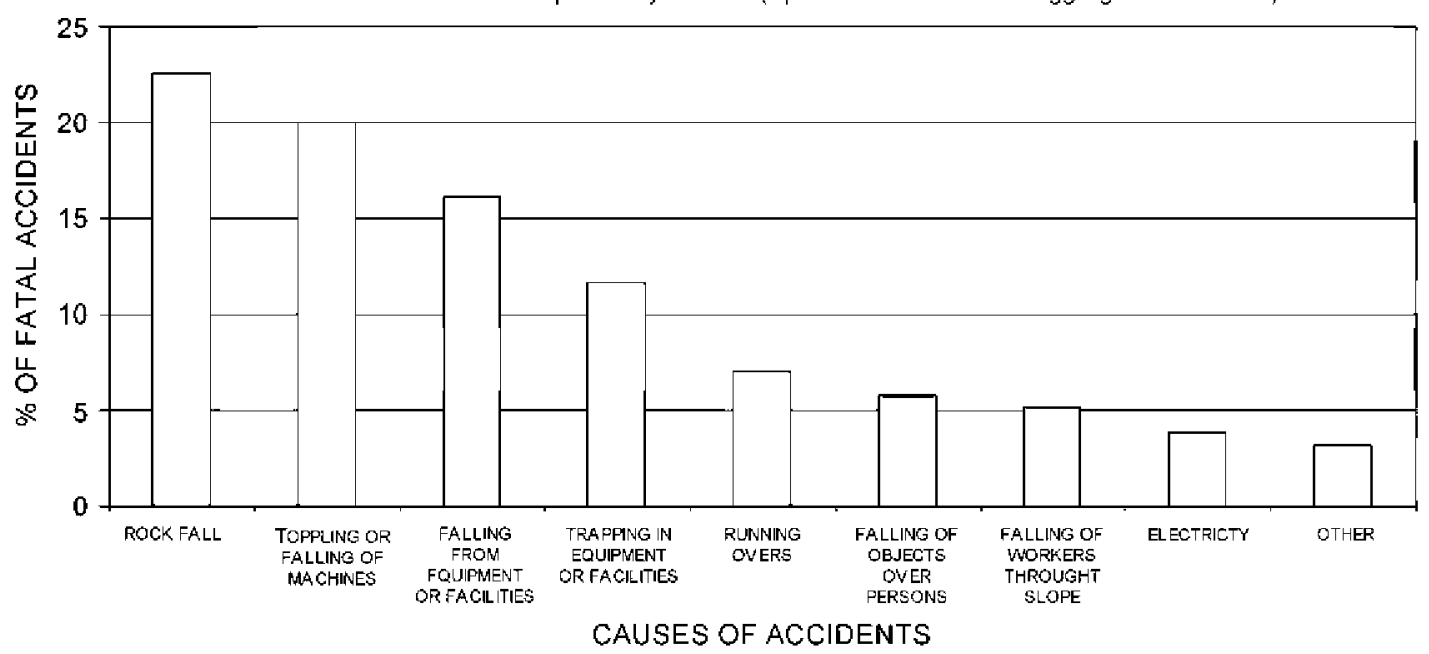

Fig. 1. Aggregate mining fatalities and their causes in Spain for the period 1987-1995 (Source: ANEFA)

preventive measures. Given the lack of suitable rockfall analysis tools for quarries, the authors developed the method described in this article.

Road and highway rockfalls have attracted a great deal of attention from both government bodies and researchers in recent years, and a number of empirical methodologies have been proposed in order to prioritise and assess rockfall hazard in road rock cuts, as well as protective works have been tested and modelled. The best known and most widely used techniques are the Rockfall Hazard Rating System (RHRS), developed for Oregon by Pierson et al. and the Rockfall Hazard Rating for Ontario (RHRON), initially proposed by Franklin and Senior and further developed by Senior As for mountain rockfall hazards affecting populated areas, Mazzocola and Hudson have described an empirical method for assessing rockfall risk for Alpine ranges. Rockfalls in open pit mines have been analysed by a number of authors, who have proposed either approaches based on simple estimates or more complex reliability-based methods aimed at maximising net profit

The study of rockfalls in quarries, however, has attracted not as much interest as rockfalls in road cuts, mountain areas and open pit mines. This is probably due to the fact that mineral reserves in the aggregate field are not usually scarce and the value of the mineral does not justify the application of costly reliability-based methods.

Empirical methods are not the only approach to dealing with the rockfall problem. Theoretical fall paths and trajectories have been extensively researched in laboratories and in situ by a range of authors, including Giani Hungr and Evans Bozzolo et al. , Fornaro et al. Azzoni and de Freitas [19], and more recently, Giani et al. There are also a series of lumped mass method based codes for performing two-dimensional (RocFall and CSRP ) or three-dimensional fall path analyses for different slope geometries.
The range of techniques applied to mitigating the risk associated with rockfalls has been reviewed by Fookes and Sweeney and Spang and Rautenstrauch The most common remedial measure for roads is the excavation of a ditch, whose geometry and dimensions can be estimated according to Ritchie and Pierson et al. The typical preventive approach for open pit mines and quarries is slope benching, which can be dimensioned according to Alejano et al.

There are important differences between road rock cuts and quarry or open pit mining slopes, in terms of designedin safety levels, geometric characteristics (benches, berms and catch-benches for mines, rock cuts with ditches for roads), and the potential target of the accident (miners and machinery in mines, the general public and vehicles on roads). Mines are also dynamic environments, featured by continuously changing slopes and blasting operations. Empirical methods specifically designed for roads are therefore not suitable for application to mines. The authors developed the empirical method for estimating potential rockfall risk with quarries in mind. Called ROFRAQ, the approach is solidly grounded in rock mechanics and relies on a probabilistic approach based on observations in quarries.

\section{ROFRAQ}

Rockfall Risk Assessment for Quarries (ROFRAQ) is an empirical method for assessing rockfall hazard in hard rock quarries and open pit mines in temperate climate regions. The method is based on the observation that a rockfallrelated accident in a mining environment typically occurs as a consequence of five sequential events, as follows: $(A)$ a detached block/rock mass exists on a slope, $(B)$ the block/rock mass is close to equilibrium (under any given instability mechanism), (C) a triggering phenomenon makes the block/rock mass unstable, $(D)$ the block/rock 
mass fall path is such that one or more blocks reach the quarry bottom and finally $(E)$ at least one block hits a worker or a machine.

The probability of an accident occurring, which is the probability of these five events taking place sequentially, can be calculated by multiplying the individual factor probabilities. Thus, the method has a multiplicative structure (as in the Q-system of rock classification rather than an additive structure (as in RHRS

\section{or RHRON which recall Bieniawski's Rock}

Mass Rating system ). In the method, a score of between 0 and 10 is assigned to each of these possible events (assigned labels $A-E$ ) on the basis of an assessment and weighting of all the factors that affect the occurrence of the rockfall. In developing the method, the authors drew on analyses of rockfalls in road cuts and slopes [9-11] and on their experience of mine slope stability analysis and design [36,37]. The final values were adapted to up-to-date observations made in hard rock quarries.

The product of all the factors, plus a final corrective value based on the rockfall history of the quarry (rating $F$ in the proposed method), yields an empirical final value for our ROFRAQ index, which provides a yearly estimate of the likelihood of a rockfall-related accident occurring on any given quarry slope. The ROFRAQ value is updated as remedial and safety measurements are implemented.

An insightful observation or sensitivity analysis of the method would indicate that the most significant ROFRAQ rating is $E$, which represents the likelihood of a falling block actually hitting a machine or worker. To measure the likelihood of a rockfall occurring on a slope, irrespective of the final outcome (accident/no accident), a primary version of the ROFRAQ index is proposed, called ROFRAQ ${ }_{\text {BASIC }}$, based only on the first four ratings $(A-D)$. This basic version reflects the fact that, in previous versions of the model dangerous slopes, on or below which (according to the mining plan), no machines were likely to be operating, had been paradoxically rated as low risk slopes - a fact which does not make them less dangerous. ROFRAQ ${ }_{\text {BASIC }}$ also offers the possibility of correlating results with those for primary versions of other rockfall methods (e.g., RHRS RHRON ).

\subsection{Data and information sources}

To apply ROFRAQ to a quarry, the following background information is needed: (i) a topographical map of the quarry, drawn to an appropriate scale (1/500 to $1 / 2000$ ), (ii) the annual mining plan (including data on areas and tons to be mined, projected blasting, machinery and working cycles, and catch-bench and bench cleanup practices), (iii) meteorological data for the mine area (maximum daily rainfall and frost-free period for $0^{\circ} \mathrm{C}$ ) and (iv) a discontinuity survey (following the indications of the
ISRM [38] and including at least 100 significant joints for structurally homogeneous rock masses).

On the basis of this information, the quarry or mine is divided into a number of slope faces, with orientations maintained constant. These slope faces are the unit of application of the method. If a slope is too long or heterogeneous, it is sub-divided into two or more faces. A maximum length of $100 \mathrm{~m}$ is recommended to minimise data handling problems.

One or more in situ visits are needed to record specific data for the slope faces, as follows: faults, overbreak, bench and catch-bench cleanup, rock blocks on the benches, fallen rocks in the catch-benches and at the mine bottom (a simple description and volume estimate), pictures and descriptions of local instabilities with an indication of failure mechanisms, volume and features of the instability, details of water in the slope, weathering and or erosion if significant, catch-bench conditions, and face irregularity.

It is also advisable to spend some time observing mining operations (haulage, transport, blasting, cleaning, etc.) to obtain a clear understanding of the processes and to observe how the mining plan is implemented. If possible, the quarry manager and miners should be asked about any recent accidents or significant rockfall episodes and about the circumstances surrounding these events.

\section{Calculating ROFRAQ}

The procedure for completing the ROFRAQ datasheet (illustrated in Fig. 2) in order to calculate the ROFRAQ index is described below. Authors' discussion focuses largely on how to obtain the necessary information and on the more difficult items to assess. The case study in Section 4 below further illustrates application of the method.

\subsection{Rating A. Are there potential falling blocks?}

Although this rating proved to be one of the least significant factors in the cases analysed by us, it may be important for very lightly fractured rock masses. Subratings $A(a)$ (joint sets) and $A(b)$ (joint continuity) are obtained from the discontinuity survey, which provides information on the number of joint sets and their features, including persistence or continuity. Sub-ratings $A(c)$ (faults), $A(d)$ (observed overblasting damage) and $A(e)$ (bench and berm cleanup) are recorded from in situ observations for each slope. Sub-rating $A(f)$ (blocks on slopes), which is by far the most significant of the $A$ subratings, is based on a weighting of joint survey results with in situ observation. Sub-rating $A(g)$ (slope height) is obtained from the quarry map, and the final $A$ rating is calculated according to the formula as follows:

$$
A=\left\{\frac{[A(a) A(b)+A(c)+A(d)+A(e)]+A(f)}{2}\right\} A(g) .
$$


Rockfall Risk Assessment for Quarries (ROFRAQ)

\begin{tabular}{|c|c|c|c|c|c|c|c|c|c|c|c|c|c|c|c|}
\hline \multicolumn{16}{|l|}{ luarry: } \\
\hline \multirow{2}{*}{$\begin{array}{c}\text { ARE THERE } \\
\text { POTENTIAL } \\
\text { FALLING } \\
\text { BLOCKS? }\end{array}$} & \multicolumn{2}{|c|}{$\begin{array}{l}\text { Joint } \\
\text { sets } \\
\text { (a) }\end{array}$} & \multicolumn{2}{|c|}{$\begin{array}{l}\text { Joint } \\
\text { continuity } \\
\text { (b) }\end{array}$} & \multicolumn{2}{|c|}{$\begin{array}{l}\text { Faults } \\
\text { (c) }\end{array}$} & \multicolumn{2}{|c|}{$\begin{array}{c}\text { Observed } \\
\text { overblasting damage } \\
\text { (d) }\end{array}$} & \multicolumn{2}{|c|}{$\begin{array}{c}\text { Bench \& } \\
\text { berm cleanup } \\
\text { (e) }\end{array}$} & \multicolumn{2}{|c|}{$\begin{array}{l}\text { Blocks on } \\
\text { slopes } \\
\text { (f) }\end{array}$} & \multicolumn{2}{|c|}{$\begin{array}{c}\text { Slope } \\
\text { height } \\
\text { (g) }\end{array}$} & \multirow{5}{*}{$\begin{array}{c}A=\left\{\left[\left(a^{\star} b\right)\right.\right. \\
+c+d+e \\
+f] / 2\}^{\star} g \\
0<A<10\end{array}$} \\
\hline & 2 & 1 & $1-3 m$ & 0.8 & Small $\times 1$ & 0.5 & Half-barrels & -0.5 & Regular & -1 & Several & $3-7$ & $50 \mathrm{~m}$ & 0.8 & \\
\hline \multirow{3}{*}{$a$} & 3 & 3 & $3-10 \mathrm{~m}$ & 1 & Large $\times 1$ & 1 & None & 0 & Occasional & 0 & Some & $1-3$ & $100 \mathrm{~m}$ & 1 & \\
\hline & 4 & 5 & $10-20 \mathrm{~m}$ & 1.2 & 2 & 1.5 & Slight & 1 & Infrequent & 1 & Few & $0.1-1$ & $150 \mathrm{~m}$ & 1.3 & \\
\hline & $>5$ & 7 & $>20 \mathrm{~m}$ & 1.4 & $>2$ & 2 & Excess. overbreak & 2.5 & Little'none & 3 & None & $0.0-0.1$ & $>250 \mathrm{~m}$ & 1.5 & \\
\hline
\end{tabular}

\begin{tabular}{|c|c|c|c|c|c|c|c|c|c|c|c|}
\hline \multirow{5}{*}{$\begin{array}{c}\text { ARE THE } \\
\text { BLOCKS } \\
\text { POTENTIALLY } \\
\text { UNSTABLE? } \\
\text { b }\end{array}$} & \multicolumn{11}{|c|}{$\begin{array}{l}\text { GEOTECHNICAL STUDY + JOINT DATA INTERPRETATION + IN SITU OBSERVATION/RECORDING OF SLOPE LOCAL AND GENERAL } \\
\text { INSTABILITY MECHANISMS }\end{array}$} \\
\hline & SIMPLE & $\begin{array}{c}B^{*} \\
\left({ }^{*} 0.8\right)\end{array}$ & COMPLEX & $\begin{array}{c}B^{*} \\
(* 1.1)\end{array}$ & EVOLUTIVE & $\begin{array}{c}B^{*} \\
(* 1.4)\end{array}$ & & $\begin{array}{l}\text { IN-SITU } \\
\text { OBS. }\end{array}$ & $\begin{array}{l}\text { GEOTECH. } \\
\text { STUDY }\end{array}$ & $\begin{array}{l}\text { FALLEN BLOCKS } \\
\text { AT SLOPE TOE }\end{array}$ & $\begin{array}{l}\text { AVERAGE } \\
\left.\text { (correct. } \mathbf{B}^{*}\right) \mathbf{P}_{\mathbf{1}}\end{array}$ \\
\hline & Wedge failure & & Many blocks & & Flexural toppling & & B & & & & \\
\hline & Circular failure & & Free blocks & & Foolwall slopes & & C & & & & \\
\hline & $\mathrm{B}^{\mu}$ is a correctior & factor & cording to failur & mechan & ism complexity & & D & & & & \\
\hline
\end{tabular}

\begin{tabular}{|c|c|c|c|c|c|c|c|c|c|c|c|}
\hline \multirow{3}{*}{$\begin{array}{c}\text { IS A } \\
\text { TRIGGERING } \\
\text { EFFECT LIKELY } \\
\text { TO PRODUCE } \\
\text { INSTABILITY? } \\
\text { Triggering } \\
\text { Phenomena }\end{array}$} & \multicolumn{2}{|c|}{$\begin{array}{l}\text { Max. 24h rainfall for a } \\
50 \text {-year return period } \\
\text { (a) }\end{array}$} & \multicolumn{2}{|c|}{$\begin{array}{l}\text { Average } 0^{\circ} \mathrm{C} \text { frost-free } \\
\text { period (days) } \\
\text { (b) }\end{array}$} & \multicolumn{2}{|c|}{$\begin{array}{l}\text { Slope water } \\
\text { (c) }\end{array}$} & \multicolumn{2}{|c|}{$\begin{array}{l}\text { Weathering/erosion } \\
\text { (d) }\end{array}$} & \multicolumn{2}{|c|}{$\begin{array}{c}\text { Blasting vibration } \\
\text { (specific load) } \\
\text { (e) }\end{array}$} & \multirow{4}{*}{$\begin{array}{c}c=a+b+c+d+e \\
0<c<10\end{array}$} \\
\hline & $<50 \mathrm{~mm}$ & 0.1 & $>300$ & 0.1 & Dry & 0 & Unweathered & 0 & $<250 \mathrm{gr} / \mathrm{m}^{3}$ & 0.1 & \\
\hline & $80-110 \mathrm{~mm}$ & 1.5 & $200-250$ & 1 & Wet & 0.3 & Weathered & 0.3 & $400-550{\mathrm{gr} / \mathrm{m}^{3}}^{3}$ & 1 & \\
\hline C & $110-150 \mathrm{~mm}$ & 4 & $150-200$ & 2 & Dripping & 0.7 & Very weathered & 0.7 & $550-700 \mathrm{gr} / \mathrm{m}^{3}$ & 1.5 & \\
\hline
\end{tabular}

\begin{tabular}{|c|c|c|c|c|c|c|c|c|c|c|c|c|c|c|c|c|c|}
\hline \multirow{5}{*}{$\begin{array}{c}\text { ARE THE } \\
\text { BLOCKS LIKELY } \\
\text { TO REACH THE } \\
\text { MINE BOTTOM? } \\
\text { d }\end{array}$} & \multicolumn{10}{|c|}{$\begin{array}{c}\text { Bench height }(\mathrm{m}) \\
\& \\
\text { Berm/catch-bench width }[\mathrm{BW}](\mathrm{m}) \\
10\end{array}$} & \multirow{3}{*}{\multicolumn{2}{|c|}{$\begin{array}{l}\text { General } \\
\text { slope dip } \\
\text { (a) }\end{array}$}} & \multirow{3}{*}{\multicolumn{2}{|c|}{$\begin{array}{l}\text { Berm } \\
\text { conditions \& } \\
\text { cleanup } \\
\text { (b) }\end{array}$}} & \multirow{2}{*}{\multicolumn{2}{|c|}{$\begin{array}{l}\text { Face irregularity } \\
\text { (c) }\end{array}$}} & \multirow{5}{*}{$\begin{array}{c}\mathrm{D}=\left(\mathrm{D}_{\mathrm{b}}+\mathrm{a}+\mathrm{b}+\right. \\
\mathrm{c})^{\star} \mathrm{d} \\
0<\mathrm{D}<10 \\
\\
\begin{array}{c}\text { Estimated } \\
\text { probability of } \\
\text { block reaching } \\
\text { mine bottom } \\
\text { (RockFall) }\end{array}\end{array}$} \\
\hline & \multicolumn{2}{|c|}{5} & \multicolumn{2}{|c|}{10} & \multicolumn{2}{|c|}{12} & \multicolumn{2}{|c|}{15} & \multicolumn{2}{|c|}{20} & & & & & & & \\
\hline & Bw & $\mathrm{D}_{\mathrm{b}}$ & BW. & $\mathrm{D}_{\mathrm{b}}$ & BW & $\mathbf{D}_{\mathbf{b}}$ & BW & $\mathrm{D}_{\mathrm{b}}$ & BW & $\mathbf{D}_{\mathrm{b}}$ & & & & & High & +2 & \\
\hline & 1.5 & 7 & 2 & 9 & 3 & 8 & 4 & 9 & 5 & 9.5 & $48^{\circ}$ & +1 & Good & +0.5 & Low & 0 & \\
\hline & $\begin{array}{c}2 \\
2.5\end{array}$ & $\begin{array}{l}4 \\
1\end{array}$ & $\begin{array}{l}3 \\
4\end{array}$ & $\begin{array}{l}6 \\
2\end{array}$ & $\begin{array}{l}4 \\
5\end{array}$ & $\begin{array}{c}5 \\
2.5\end{array}$ & $\begin{array}{l}5 \\
6\end{array}$ & $\begin{array}{l}6 \\
3\end{array}$ & $\begin{array}{c}6 \\
7.5\end{array}$ & $\begin{array}{l}7.5 \\
2.5\end{array}$ & $\begin{array}{l}56^{\circ} \\
60^{\circ}\end{array}$ & $\begin{array}{c}+0.5 \\
0\end{array}$ & $\begin{array}{c}\text { Limited } \\
\text { Poor }\end{array}$ & $\begin{array}{c}+1 \\
+1.5\end{array}$ & Mesh & hes & \\
\hline
\end{tabular}

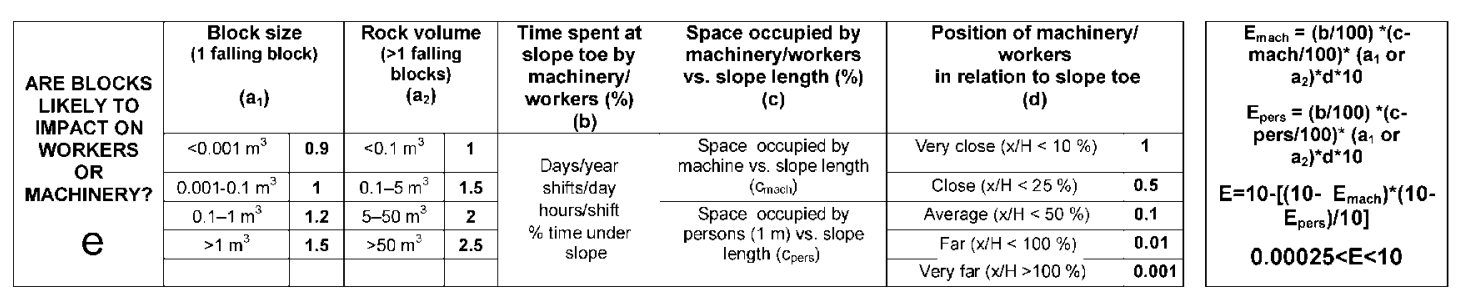

\begin{tabular}{|c|c|c|c|c|c|c|}
\hline$f$ & \multicolumn{7}{|c|}{ SLOPE ROCKFALL HISTORY } \\
\hline $\begin{array}{c}\text { No recorded } \\
\text { rockfalls }\end{array}$ & $\begin{array}{c}\text { Very few } \\
\text { rockfalls }\end{array}$ & $\begin{array}{c}\text { No data } \\
\text { Unreliable observations }\end{array}$ & $\begin{array}{c}\text { Occasional } \\
\text { rockfalls }\end{array}$ & $\begin{array}{c}\text { Several rockfalls } \\
\text { No accidents }\end{array}$ & $\begin{array}{c}\text { Some rockfalls } \\
\text { 1 reported accident }\end{array}$ & $\begin{array}{c}\text { Frequent rockfalls } \\
>1 \text { reported accident }\end{array}$ \\
\hline $\mathbf{0 . 7 5}$ & $\mathbf{0 . 9}$ & $\mathbf{1 . 0}$ & $\mathbf{1 . 1}$ & $\mathbf{1 . 2}$ & $\mathbf{1 . 4}$ & $\mathbf{1 . 5}$ \\
\hline
\end{tabular}

ROFRAQ $=(A \times B \times C \times D \times E \times F)=$

ROFRAQ $_{\text {pers }}=\left(A \times B \times C \times D \times E_{\text {pers }} \times F\right)=$
ROFRAQ $_{\text {BASIC }}=(A \times B \times C \times D)=$

$R_{\text {OFRAQ }}$ mach $=\left(A \times B \times C \times D \times E_{\text {mach }} \times F\right)=$

Estimated probability of an accident due to rockfall occurring on the slope $=\operatorname{ROFRAQ} / 100,000=$

\begin{tabular}{|c|c|ccc|c|}
\hline \multicolumn{5}{|c|}{ Preliminary assessment of the quarry face hazard according to ROFRAQ results } \\
\hline Less than 10 & $\mathbf{1 0 - 2 5}$ & $\mathbf{2 5 - 1 0 0}$ & $\mathbf{1 0 0 - 2 5 0}$ & $\mathbf{2 5 0 - 1 0 0 0}$ & More than 1000 \\
\hline $\begin{array}{c}\text { VERY LOW RISK } \\
\text { No special } \\
\text { measures required. }\end{array}$ & $\begin{array}{c}\text { LOW RISK } \\
\text { Simple precautionary } \\
\text { measures required } \\
\text { (inc. regular } \\
\text { observation) }\end{array}$ & $\begin{array}{c}\text { LOW TO AVERAGE RISK } \\
\text { Some simple safety } \\
\text { precautions required e.g. } \\
\text { avoid traffic under slope } \\
\text { during rainy periods, etc. }\end{array}$ & $\begin{array}{c}\text { AVERAGE RISK } \\
\text { lmpottant safety measures } \\
\text { required. Improve berms and } \\
\text { catch-benches, cleanup. } \\
\text { blasting control techniques; etc. }\end{array}$ & $\begin{array}{c}\text { Highly hazardous. } \\
\text { Redraft mining plan, } \\
\text { enlarge catch-benches, } \\
\text { redesign locally, etc. }\end{array}$ & $\begin{array}{c}\text { VERY HIGH RISK } \\
\text { install meshn quarry, } \\
\text { ditches, etc. }\end{array}$ \\
\hline
\end{tabular}

Fig. 2. ROFRAQ datasheet for estimating rockfall risk in quarry slopes.

\subsection{Rating B. Are the blocks potentially unstable?}

This is possibly the most complex rating to estimate, and the authors propose estimating it as follows. First of all, bearing in mind joint data and bench orientation and dip, conduct a classical study of the slope face instability mechanisms (following Hoek and Bray or Hudson and Harrison , in order to check for the occurrence of 
planar, wedge or toppling failures (and other types of failure mechanisms, such as footwall slope instability). Secondly, based on this analysis and taking into account joint spacing and continuity, estimate the percentage of the slope face likely to be affected by each type of mechanism. This estimate may be facilitated by a representation of joint intersections in the slope face (using the UDEC code for example, or any other tool for representing joint sets).

A visit to the quarry will serve to confirm these mechanisms and identify any others not detected using the techniques mentioned above. For each mechanism, the degree to which the slope face is affected is recorded as a percentage, first on the basis of in-place observations of the benches, second as derived from the geotechnical classical study of slope instability mechanisms and third, according to the in situ occurrence of rock blocks at the foot of the slope benches. The different percentages reflecting the affected area of the slope are recorded in the ROFRAQ datasheet and then averaged and weighted according to the formula provided. The final value for the $B$ rating is then calculated as:

$B=10\left\{1-\left[\prod_{i=1}^{n}\left(1-\frac{P_{i}}{100}\right)\right]\right\}$.

\subsection{Rating C. Is a triggering effect likely to produce instability?}

This rating is calculated as follows. Sub-ratings $C(a)$ (maximum $24 \mathrm{~h}$ rainfall for a 50 -year return period) and $C(b)$ (average $0{ }^{\circ} \mathrm{C}$ frost-free period in days) are based on historical meteorological data, which can be obtained from the nearest meteorological station. (In some countries maps are available that contain this information.) Sub-ratings $C(c)$ (slope water) and $C(d)$ (weathering/erosion) are based on observations in the field (in a similar way to the rock mass classification approach). Finally, sub-rating $C(e)$ (blasting vibration) is based on the general blasting programme as described in the mining plan. The final $C$ rating is calculated according to the following formula

$C=C(a)+C(b)+C(c)+C(d)+C(e)$.

It is important to note that, to a large degree, rating $C$ reflects local conditions and so would need to be adapted for application to other climate conditions.

\subsection{Rating D. Are blocks likely to reach the mine bottom?}

ROFRAQ is calculated using the datasheet illustrated in Fig. 2. In what concerns rating $D$, some comments are made about a number of graphs (Figs. 3 and 4) that are necessary for calculating ROFRAQ $D$ sub-ratings and ratings. Fig. 3 shows how to estimate $\left[D_{b}+D(a)\right]$ subrating, which takes into account general slope and bench geometry in order to estimate the percentage of falling blocks that might reach working areas; $D_{b}+D(a)$ is graphed using the results of the RocFall lumped-mass method with input represented by average hard rock parameters. Fig. 4, based on shows estimates of face irregularity (used to calculate $D(c)$ ).

It has been observed that the two most significant parameters affecting the likelihood of a block reaching the quarry bottom are catch-bench width and bench height. Consequently, the most significant sub-rating, $D_{b}$, is based on these two features. $D_{b}$ is calculated from a series of more than 100 regular slope simulations using the RocFall code

and the results are recorded in the corresponding section in the datasheet in Fig. 2. Empirical observation would indicate that the results obtained are consistent with the level of accuracy aimed at for the proposed empirical method; for particular cases such as more than $20 \mathrm{~m}$ high bench slopes, soil slopes, non-benched low angle slopes or very irregular ones, however, this approach should not be taken as reliable and a rockfall code should be used.

General slope dip, $D(a)$, which is affected by bench slope, is estimated from the topographical map. Results for a series of typical cases for $D_{b}+D(a)$ are depicted in Fig. 3 . Sub-ratings $D(b)$ (Berm conditions and cleanup), $D(c)$ (face irregularity) and $D(d)$ (mesh/ditches) are recorded from field observations, as indicated in the table. The estimate for sub-rating $D(c)$, referring to face irregularity, can be based on Fig. 4. The final $D$ rating is calculated according to the following formula

$D=\left[D_{b}+D(a)+D(b)+D(c)\right] \times D(d)$.

\subsection{Rating E. Are blocks likely to impact on workers or machinery?}

A rockfall means for the authors an instability affecting a single bench. Bearing this in mind, sub-ratings $E(a 1)$ (block size) and $E(a 2)$ (rock volume), indicating the volume of rockfall, are based on in situ observations. Sub-ratings $E(b)$ (time spent at slope by machinery/workers) and $E(c)$ (space occupied by machinery/workers vs. slope length) are informed by the yearly mining plan, which described the time spent and space occupied by equipment and/or workers during common work routines on any given slope. Sub-rating $E(d)$ (position of machinery/workers in relation to slope toe), which reflects impact probability on the basis of machine and worker locations, is calculated as in Fig. 5. More details on how this rating is calculated are given in the case study described in the next section. ROFRAQ also provides a differentiated $E$ rating for machines $\left(E_{\text {mach }}\right)$ and for workers ( $\left.E_{\text {pers }}\right)$. The reason for this calculation is that, in particular quarries, there are many manual workers for whom the risk of a fatality is higher than for workers protected by machinery. The $E$ rating, which is usually the 'limiting' rating for the entire classification, has a minimum value of 0.00025 , corresponding to a person spending $8 \mathrm{~h}$ a year under a $100 \mathrm{~m}$ long slope face. Rating $E$ is then obtained by applying the following formulae $\left(c_{\text {mach }}\right.$ is the percentage of slope length space occupied by machinery 

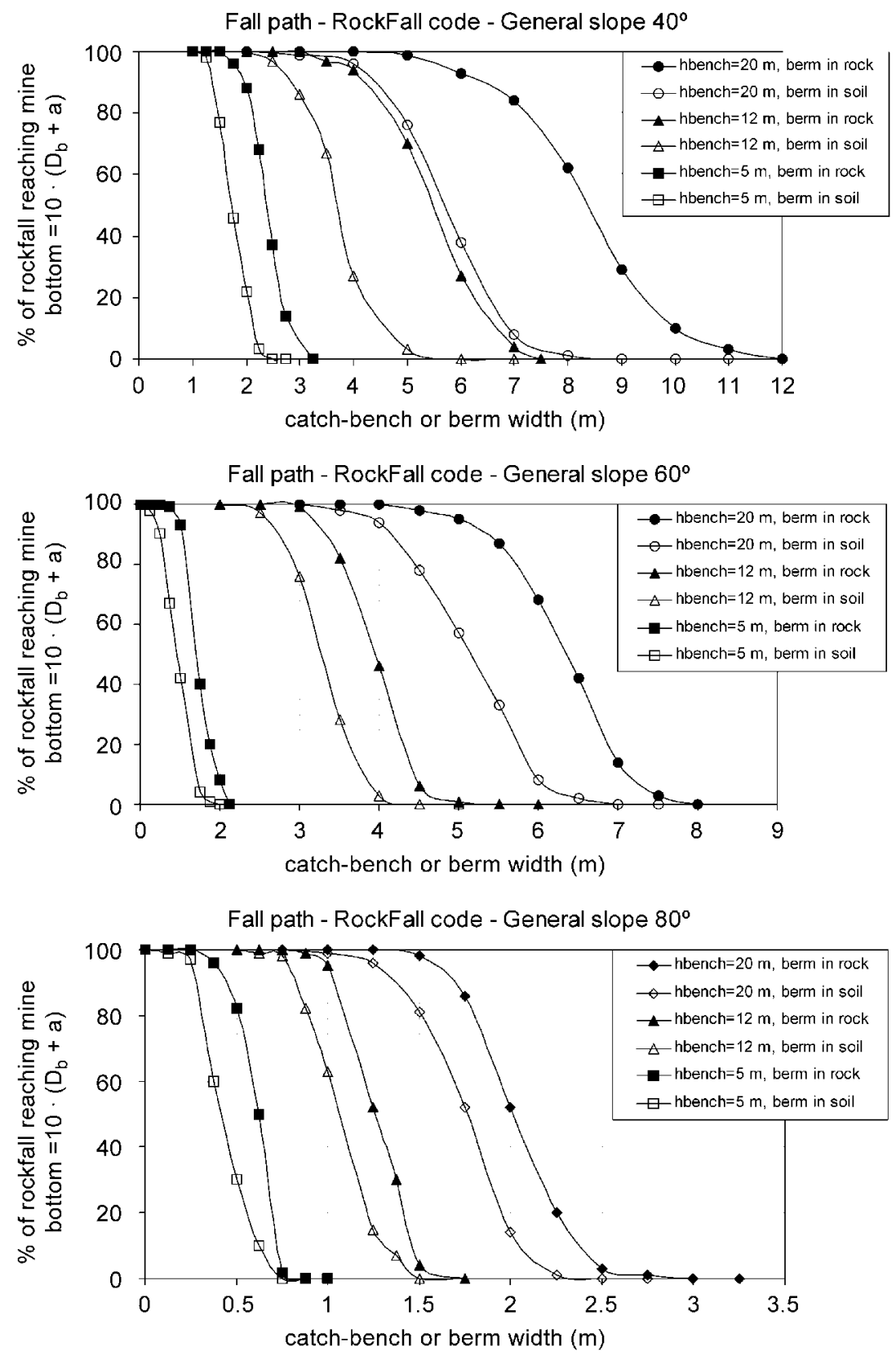

Fig. 3. Reach estimates for rock blocks falling down mining slopes (used to calculate sub-ratings $D_{h}+D(a)$ ).

and $c_{\text {pers }}$ is the percentage of slope length space occupied by persons)

$E_{\text {mach }}=\left(\frac{E(b)}{100}\right) \times\left(\frac{c_{\text {mach }}}{100}\right) \times\left(a_{1}\right.$ or $\left.a_{2}\right) \times(E(d)) \times 10$,

$E_{\mathrm{pers}}=\left(\frac{E(b)}{100}\right) \times\left(\frac{c_{\text {pers }}}{100}\right) \times\left(a_{1}\right.$ or $\left.a_{2}\right) \times(E(d)) \times 10$,

$E=10-\left[\frac{\left(10-E_{\text {mach }}\right) \times\left(10-E_{\text {pers }}\right)}{10}\right]$.
An insightful observation or sensitivity analysis of the method would indicate that the most significant ROFRAQ rating is $E$, which represents the likelihood of a falling block actually hitting a machine or worker. To measure the likelihood of a rockfall occurring on a slope, irrespective of the final outcome (accident/no accident), a primary version of the ROFRAQ index is proposed, called ROFRAQ ${ }_{\text {BASIC, }}$ based only on the first four ratings $(A-D)$. This basic version reflects the fact that, in previous versions of the model dangerous slopes, on or below which (according to the mining plan), no machines were likely to be operating, had been paradoxically rated as low risk slopes - a fact which does not make them less dangerous. ROFRAQBASIC also offers the possibility of correlating 
FACE IRREGULARITY

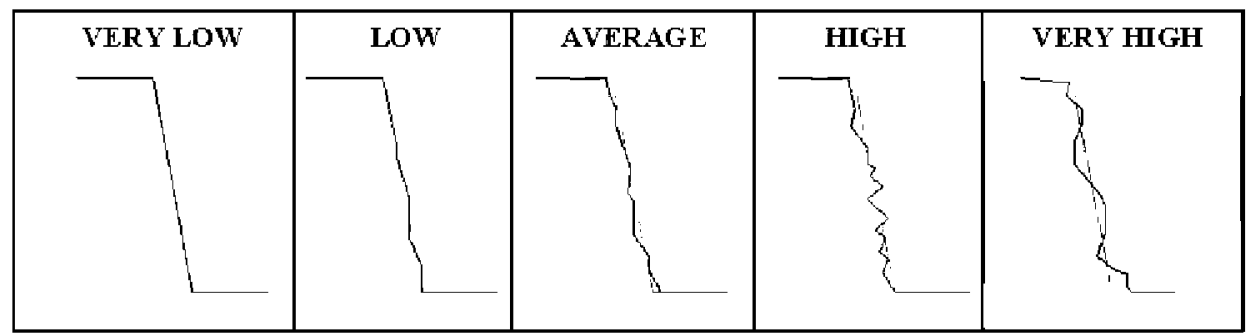

VERY LOW,- More than $80 \%$ of half-barrels related to blast-hole length are observed in the slope face.

LOW.- Between 40 and $80 \%$ of half-barrels can be observed in the slope face.

AVERAGE.- Between 10 and $40 \%$ of half-barrels can be observed in the slope face. A shotcrete layer up to $20 \mathrm{~cm}$ is enough to give a locally smooth face.

HIGH.-A shotcrete layer between 20 and $50 \mathrm{~cm}$ is needed to give a locally smooth face. Maximum depth of overhangs is $0.5 \mathrm{~m}$.

VER Y HIGH.- Overhang depth over $0.5 \mathrm{~m}$.

Fig. 4. Face irregularity (used to calculate sub-rating $D(c)$ ). Based on an approach by Senior

\section{LOCATION OF WORKERS AND MACHINERY IN RELATION TO SLOPE TOE}

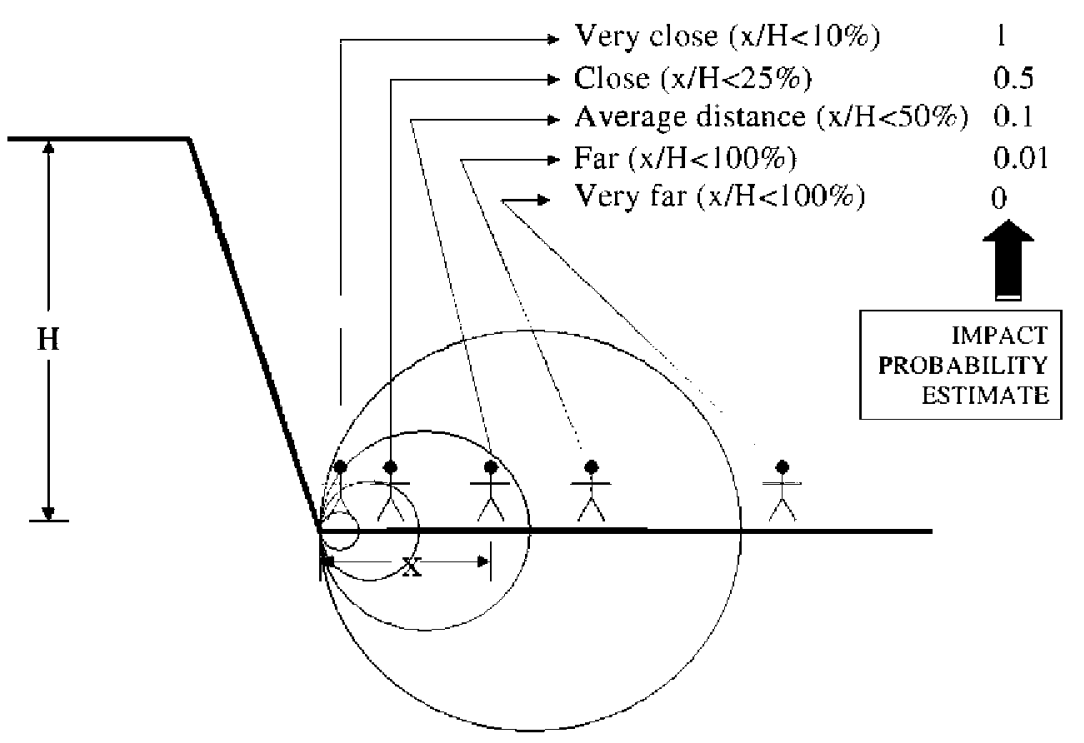

Fig. 5. Location of workers and machinery in relation to slope toe (used to calculate sub-rating $E(d)$ ).

results with those for primary versions of other rockfall methods (e.g., RHRS [9,32,33] or RHRON [10,11]).

\subsection{Rating F. Quarry/slope rockfall history}

This rating is estimated on the basis of official accident records, if available, and mine manager and/or worker observations. The value of any information considered to be possibly unreliable is set at 1 .

Once obtained the ratings $A, B, C, D$ and $F$, ROFRAQ index is calculated according the following formulae:

$\mathrm{ROFRAQ}_{\mathrm{BASIC}}=A \times B \times C \times D$,

$$
\begin{aligned}
& \text { ROFRAQ }_{\text {mach }}=A \times B \times C \times D \times E_{\text {mach }} \times F, \\
& \text { ROFRAQ }_{\text {pers }}=A \times B \times C \times D \times E_{\text {pers }} \times F, \\
& \text { ROFRAQ }=A \times B \times C \times D \times E \times F .
\end{aligned}
$$

\section{A case study}

The authors present an application of the ROFRAQ methodology. First the quarry where the analysis was performed is described, and then the preliminary information used to apply the method is described.

The quarry was divided into slope faces, and the case study application focuses on the ROFRAQ index 
calculation for the slope identified as one of the most hazardous slopes in the quarry by the quarry manager. The authors describe in detail the calculation of each sub-rating and rating, which together, provide a final ROFRAQ value. Since the final ROFRAQ value for the studied slope indicated a high accident risk, remedial measures to mitigate this risk were recommended.

The ROFRAQ index was calculated for all the slopes in the quarry for a 4-year period. A discussion of the evolution of this index and of how the index can improve mine safety conclude this section.

\subsection{Quarry PO-01: a granite aggregate quarry}

Quarry PO-01 was studied for the years 2002-2005. It produces 600,000 tons/year of granite, which is crushed and classified as different commercial aggregate products. The material is mined from $15-\mathrm{m}$-high benches by means of blasting. The $75^{\circ}$ dipping benches consist of 4 rows of 10 blast holes each, 3 in. in diameter and $16.5 \mathrm{~m}$ long. Spacing between blast holes is $3 \mathrm{~m}$ and the burden is $2.8 \mathrm{~m}$. Blast holes are filled with $3.2-\mathrm{m}$ cartridges of a water-resistant gelatine explosive $(17.5 \mathrm{~kg})$ and $10.4-\mathrm{m}$ cartridges of raw ANFO $(37.7 \mathrm{~kg})$, which represent an average specific (ANFO-related) explosive consumption of $500 \mathrm{~g} / \mathrm{m}^{3}$ of blasted rock. Approximately 50 blasts are performed each year in the quarry, which works out at around one blast per week. Each blast yields roughly 12,000 tons of material, which is hauled and/or conveyed to the crushing plant. No waste is generated. The width of the safety berms or catchbenches ranges from 5 to $9 \mathrm{~m}$, and so the general slopes vary between $50^{\circ}$ and $60^{\circ}$ (Fig. $6 \mathrm{c}$ ).

\subsection{Data and information sources}

Before applying the ROFRAQ method to the quarry, data and information were first compiled from a topographical map of the quarry, the quarry mining plan, meteorological statistics, and a discontinuity survey.

The topographical map of the quarry (scale 1:1000) depicts the areas to be mined according to the mining plan. A diagram based on this map (for the year 2002) is depicted in Fig. 6c, which also shows the slope face divisions on the basis of which the rockfall risk assessment method was applied. The quarry was divided into 15 slope faces for analysis using ROFRAQ. Slope 10 did not exist in 2002 or 2003 , and the slope resulting from the reshaping of Slopes 11 and 12 into a new slope after 2003 was called Slope $10^{\prime}$. During 2002 , the quarry bottom was deepened by a further bench $(15 \mathrm{~m}$ high $)$, to which access was created between Slopes 1 and 15. This access was identified as a rockfall hazardous area, as it was operative until the new road on Slopes 2, 3 and 4 was completed the following year.

With regard to the mining plan, as mentioned, about 50 blasting operations - producing 12,000 tons of material each - are performed in the quarry each year. The equipment used in the quarry include a small drilling machine for making blast holes, a backhoe with a $4-\mathrm{m}^{3}$ bucket, 30-ton trucks (4), and a hammer to cleanup the bench faces and to break up bigger blocks resulting from the blast but too large to enter the primary crusher. At particularly busy periods, an additional loader (usually from the crushing plant) helps out with material haulage. The backhoe needs about 4 min (three to four buckets) to fill each truck, and haulage truck cycles are based on a

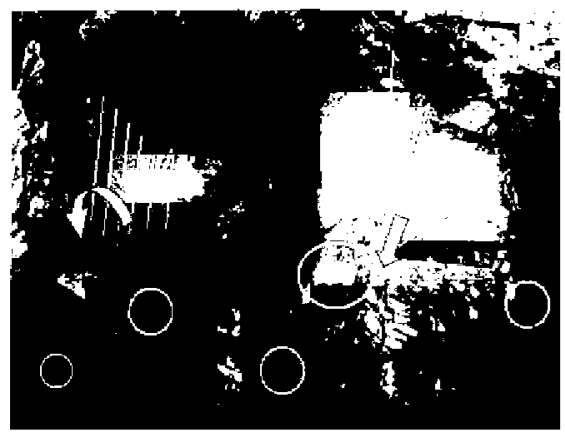

b

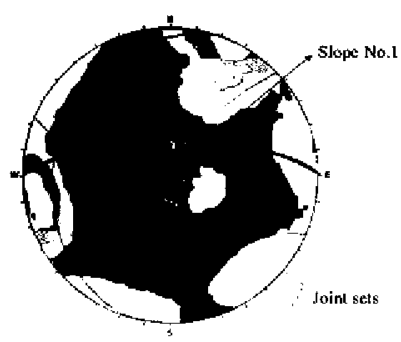

C

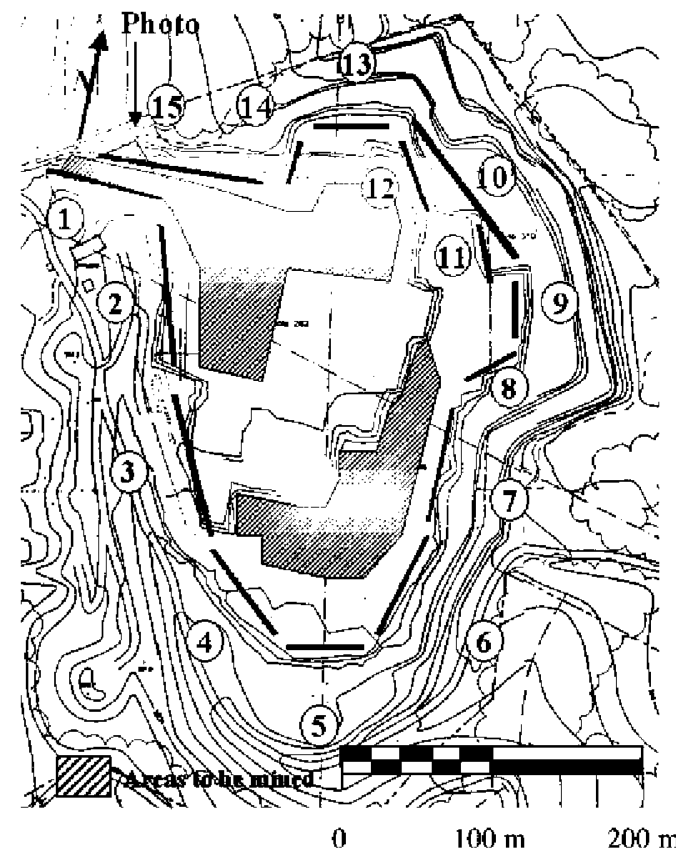

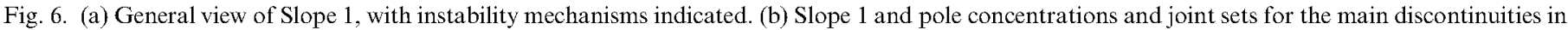
the quarry slopes. (c) Sketch of the quarry indicating slope faces (heavy black lines numbered 1-15) and the areas to be quarried (hatched areas). 
Table 1

Discontinuities and their main features

\begin{tabular}{|c|c|c|c|c|c|c|c|c|}
\hline \multirow[t]{2}{*}{ Joint set } & \multicolumn{2}{|c|}{ Dip direction $\left({ }^{\circ}\right)$} & \multicolumn{2}{|c|}{ Dip ( ) } & \multicolumn{2}{|c|}{ Persistence $(\mathrm{m})$} & \multicolumn{2}{|c|}{ Spacing $(\mathrm{m})$} \\
\hline & Mean & S.D. & Mean & S.D. & Mean & S.D. & Mean & S.D. \\
\hline 1 & 079 & 12 & 87 & 14 & 18 & 8 & 1.3 & 0.5 \\
\hline 2 & 203 & 17 & 77 & 20 & 25 & 15 & 1.5 & 0.4 \\
\hline 3 & 316 & 15 & 80 & 10 & 15 & 5 & 2.3 & 0.9 \\
\hline 4 & 087 & 12 & 22 & 7 & 11 & 8 & 2.0 & 0.5 \\
\hline
\end{tabular}

around $8 \mathrm{~min}$ to transport loads to the primary crusher, 2 min to unload and 6 min to return to the vicinity of the excavator. Consequently, the average cycle for each truck is around $20 \mathrm{~min}$. The four trucks employed in the quarry require around $40 \mathrm{~h}$ ( 1 week) to fetch the aggregate resulting from a single blast.

Meteorological data were averaged out from the data recorded in the two nearest weather stations. Maximum rainfall for a return period of 50 years was $150 \mathrm{~mm} / 24 \mathrm{~h}$. On the basis of specific climate cartography, the frost-free period for $0{ }^{\circ} \mathrm{C}$ was estimated as 265 days.

A discontinuity survey based on over 200 measurements revealed that the quarry was located in a homogeneous rock mass containing four main joint sets. Pole concentrations, joint sets and the plane for the study slope (Slope 1) are illustrated in Fig. 6b. Table 1 summarises the main statistical features for each joint set.

\subsection{Calculating ROFRAQ}

The authors now describe how a ROFRAQ value for Slope 1 in Quarry PO-01 for the year 2002 is obtained. The values recorded in the ROFRAQ datasheet for each subrating $A$ to $F$ are illustrated in Fig. 7.

\subsubsection{Rating A. Are there potential falling blocks?}

Sub-ratings $A(a)$ and $A(b)$ were obtained from the joint survey; the value for $A(a)$ was 5 , corresponding to four joint sets, and the value for $A(b)$ was 1.2 , due to the estimated continuity of between 10 and $20 \mathrm{~m}$ for most joints. One small fault was observed in the slope, hence $A(c)$ was 0.5 . Due to the excessive overbreak observed, $A(d)$ was 2.5. Face cleanup was performed as required and so $A(e)$ was set at $0 . A(f)$ refers to the presence of free blocks in the slope, and as can be observed in Fig. 6a, blocks on the slope covered approximately $70 \%$ of the face; consequently, $A(f)$ was 7 . Finally the height of the slope ranged from 30 to $50 \mathrm{~m}$, so $A(g)$ was 0.8 . Multiplying these subratings, the value obtained for rating $A$ was 6.4.

\subsubsection{Rating B. Are the blocks potentially unstable?}

The joint survey results (Fig. 6b; Table 1) indicated that the possible kinematic instability mechanisms in the slope were a toppling mechanism-probably block toppling (due to the separation in rock mass slabs through joints in joint set 2) - and a wedge mechanism sliding through the line intersecting joint sets 1 and 3 . The intersection of the mean values for these two planes dips more than the slope, but considering the orientation variability of these joints, some wedges of this type are only to be expected. Taking the continuity and spacing of these discontinuity sets and the size of the slope into account, reasonable values of $30 \%$ and $30 \%$ have been established, respectively, for the wedges from joint sets $1-3$, and for local toppling of some of the rock blocks or slabs. A detailed in situ observation of the slope identified one of these wedges from joint sets 1-3, some local block toppling, and a number of blocks on the face, which is an instability that cannot be identified by means standard analysis but only by means of in-place observation (Fig. 6a), and consequently, the degree to which the slope was affected was estimated as $20 \%, 10 \%$ and $50 \%$, respectively. Some small blocks were observed at the foot of the slope and miners had reported two large block falls (blocks measuring $0.1-1 \mathrm{~m}^{3}$ ) in recent years. Consequently, values for the affected areas, due to blocks at the slope toe as a consequence of the indicated mechanisms, were estimated as $40 \%, 20 \%$ and $50 \%$. These values yielded a value for rating $B$ of 7.54 .

\subsubsection{Rating C. Is a triggering effect likely to produce instability?}

Scores of 5 for sub-rating $C(a)$ and of 0.4 for sub-rating $C(b)$ were established on the basis of rainfall and frost-free period data, and of 0.7 and 0.3 , respectively, for sub-ratings $C(c)$ and $C(d)$, given the water and weathering observed in the slope. Although the average specific explosive consumption for this quarry was $500 \mathrm{~g} / \mathrm{m}^{3}, 750 \mathrm{~g} / \mathrm{m}^{3}$ of explosives was required in order to open the ditch needed to excavate the Slope 1 area, and so sub-rating $C(e)$ was set as 2 . The value calculated for rating $C$ was thus 8.4.

\subsubsection{Rating D. Are blocks likely to reach the mine bottom?}

The estimation of this rating was simplified due to the fact that, since there were no catch-benches in this particular slope, all falling blocks would reach the mine bottom. According to the table, for benches higher than $20 \mathrm{~m}$ and berms or catch-benches less than $4 \mathrm{~m}$ wide, 10 is the value for sub-ratings $D_{b}+D(a)$; accordingly, the value for $D$ was 10 . Fig. 9a depicts simulated falls for 100 blocks from the slope face based on the Rocfall code [21].

The ROFRAQ ${ }_{\text {BasIC }}$ value obtained for ratings $A$ to $D$ was $40.54 \%$, calculated by multiplying the individual values and dividing them by 100 , i.e. $(A \times B \times C \times D) / 100$. This value is an indicator of the probability of a block falling down the slope and reaching the mine bottom. Expressed another way, a block can be expected to detach and fall approximately every $2-3$ years.

\subsubsection{Rating E. Are blocks likely to impact on a worker or machinery?}

A value of 1.2 , corresponding to blocks of $0.1-1 \mathrm{~m}^{3}$, was set for sub-rating $E(a 1)$. Time spent and space occupied by equipment under the $110-\mathrm{m}$ long slope was calculated on a 
Rockfall Risk Assessment for Quarries (ROFRAQ)

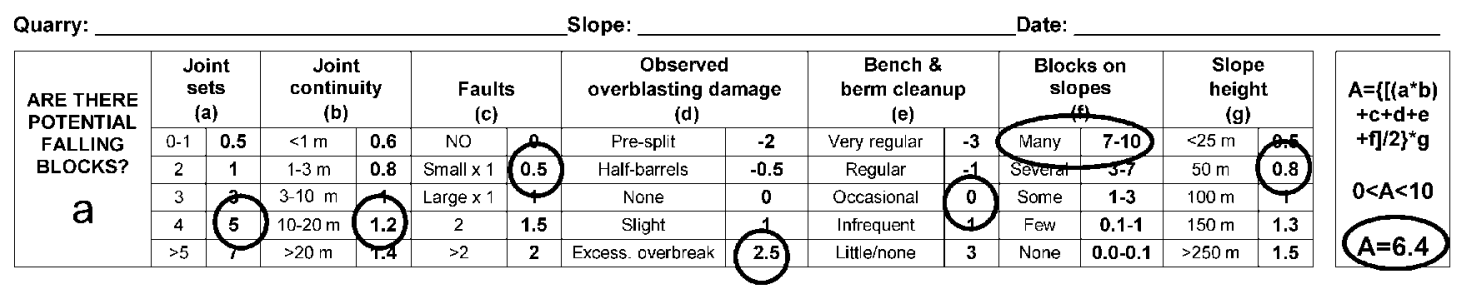

\begin{tabular}{|c|c|c|c|c|c|c|c|c|c|c|}
\hline \multirow{6}{*}{$\begin{array}{c}\text { ARE THE } \\
\text { BLOCKS } \\
\text { POTENTIALLY } \\
\text { UNSTABLE? } \\
\text { b }\end{array}$} & \multicolumn{10}{|c|}{$\begin{array}{l}\text { GEOTECHNICAL STUDY + JOINT DATA INTERPRETATION + IN SITU OBSERVATION/RECORDING OF SLOPE LOCAL AND GENERAL } \\
\text { INSTABILITY MECHANISMS }\end{array}$} \\
\hline & & \multicolumn{3}{|c|}{ Mechanism type (observed or estimated) } & estimated) & & \multicolumn{4}{|c|}{ Affected slope area $(\%)$} \\
\hline & $\begin{array}{c}\text { SIMPLE } \\
\text { Plane failure }\end{array}$ & $\begin{array}{c}B^{k} \\
\left({ }^{*} 0.8\right)\end{array}$ & $\begin{array}{l}\text { COMPLEX } \\
\text { Ravelling }\end{array}$ & $\begin{array}{c}B^{*} \\
\left({ }^{*} 1.1\right)\end{array}$ & $\begin{array}{l}\text { EVOLUTIVE } \\
\text { Block toppling }\end{array}$ & A & $\begin{array}{l}|\mathrm{N}-\mathrm{S}| \mathrm{TU} \\
\text { OBS. } \\
20 \%\end{array}$ & $\begin{array}{c}\text { GEOTECH. } \\
\text { STUDY } \\
30 \%\end{array}$ & $\begin{array}{c}\text { FALLEN BLOCKS } \\
\text { AT SLOPE TOE } \\
40 \%\end{array}$ & $\begin{array}{l}\text { AVERAGE } \\
\text { (correct. } \mathrm{B}^{*} \text { ) } \\
24 \%\end{array}$ \\
\hline & Wedge failure & & Many blocks & & Flexural toppling & B & $50 \%$ & & $50 \%$ & $55 \%$ \\
\hline & Circular failure & & Free blocks & & Footwall slopes & c & $10 \%$ & $30 \%$ & $20 \%$ & \\
\hline & \multicolumn{5}{|c|}{$\mathrm{B}^{*}$ is a correction factor according to failure mechanism complexity } & D & & & & \\
\hline
\end{tabular}

\begin{tabular}{|c|c|c|c|c|c|c|c|c|c|c|c|}
\hline \multirow{4}{*}{$\begin{array}{c}\text { IS A } \\
\text { TRIGGERING } \\
\text { EFFECT LIKELY } \\
\text { TO PRODUCE } \\
\text { INSTABILITY? } \\
\text { Triggering } \\
\text { Phenomena }\end{array}$} & \multicolumn{2}{|c|}{$\begin{array}{l}\text { Max. 24h rainfall for a } \\
50 \text {-year return period } \\
\text { (a) }\end{array}$} & \multicolumn{2}{|c|}{$\begin{array}{l}\text { Average } 0^{\circ} \mathrm{C} \text { frost-free } \\
\text { period (days) } \\
\text { (b) }\end{array}$} & \multicolumn{2}{|c|}{$\begin{array}{l}\text { Slope water } \\
\text { (c) }\end{array}$} & \multicolumn{2}{|c|}{$\begin{array}{l}\text { Weathering/erosion } \\
\text { (d) }\end{array}$} & \multicolumn{2}{|c|}{$\begin{array}{l}\text { Blasting vibration } \\
\text { (specific load) } \\
\text { (e) }\end{array}$} & \multirow[t]{2}{*}{$\begin{array}{c}C=a+b+c+d+e \\
0<C<10\end{array}$} \\
\hline & $<50 \mathrm{~mm}$ & 0.1 & $>300$ & & Dry & 0 & Unweathered & 0 & $<250 \mathrm{gr} / \mathrm{m}^{3}$ & 0.1 & \\
\hline & $50-80 \mathrm{~mm}$ & 0.5 & $250-300$ & & Damp & 0.1 & Slightly weathered & 0.1 & $250-400 \mathrm{gr} / \mathrm{m}^{3}$ & 0.5 & \\
\hline & $80-110 \mathrm{~mm}$ & 1.5 & $200-250$ & & Wet & & Weathered & & $400-550 \mathrm{gr} / \mathrm{m}^{3}$ & 1 & \\
\hline \multirow[t]{2}{*}{ C } & $110-150 \mathrm{~mm}$ & 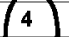 & $150-200$ & 2 & Dripping & 0.7 & Very weathered & 0.7 & $550-700 \mathrm{gr} / \mathrm{m}^{3}$ & & \\
\hline & $>150 \mathrm{~mm}$ & . & $<150$ & 2.5 & Flowing & 1 & Extremely weathered & 1 & $>700 \mathrm{gr} / \mathrm{m}^{3}$ & & \\
\hline
\end{tabular}

\begin{tabular}{|c|c|c|c|c|c|c|c|c|c|c|c|c|c|c|c|c|c|}
\hline \multirow{4}{*}{$\begin{array}{l}\text { ARE THE } \\
\text { BLOCKS LIKELY } \\
\text { TO REACH THE } \\
\text { MINE BOTTOM? }\end{array}$} & \multicolumn{10}{|c|}{$\begin{array}{c}\text { Bench height }(\mathrm{m}) \\
\mathbb{8} \\
\text { Berm/catch-bench width [BW] }(\mathrm{m})\end{array}$} & \multirow{3}{*}{\multicolumn{2}{|c|}{$\begin{array}{l}\text { General } \\
\text { slope dip } \\
\text { (a) }\end{array}$}} & \multirow{3}{*}{\multicolumn{2}{|c|}{$\begin{array}{l}\text { Berm } \\
\text { conditions \& } \\
\text { cleanup } \\
\text { (b) }\end{array}$}} & \multirow{3}{*}{\multicolumn{2}{|c|}{$\begin{array}{l}\text { Face irregularity } \\
\text { (c) }\end{array}$}} & \multirow{3}{*}{$\begin{array}{c}D=\left(D_{b}+a+b+\right. \\
c)^{\star} d \\
0<D<10\end{array}$} \\
\hline & \multicolumn{2}{|c|}{5} & \multicolumn{2}{|c|}{10} & \multicolumn{2}{|c|}{12} & \multicolumn{2}{|c|}{15} & \multicolumn{2}{|c|}{20} & & & & & & & \\
\hline & BW & $D_{b}$ & BW. & $\mathrm{D}_{\mathrm{b}}$ & BW & $D_{b}$ & BW & $\mathrm{D}_{\mathrm{b}}$ & BW & & & & & & & & \\
\hline & 15 & 7 & 2 & 9 & 3 & 8 & 4 & 9 & 5 & 9.5 & $48^{\circ}$ & +1 & Good & +0.5 & Low & & \\
\hline$d$ & 2 & 4 & 3 & 6 & 4 & 5 & 5 & 6 & 6 & 7.5 & $56^{\circ}$ & +0.5 & Limited & +1 & Mesh & & \\
\hline$u$ & 2.5 & 1 & 4 & 2 & 5 & 2.5 & 6 & 3 & 7.5 & 2.5 & $60^{\circ}$ & & Paor & +1.5 & & & reaching \\
\hline
\end{tabular}

\begin{tabular}{|c|c|c|c|c|c|c|c|c|}
\hline \multirow{5}{*}{$\begin{array}{c}\text { ARE BLOCKS } \\
\text { LIKELY TO } \\
\text { IMPACT ON } \\
\text { WORKERS } \\
\text { OR } \\
\text { MACHINERY? } \\
\text { e }\end{array}$} & \multicolumn{2}{|c|}{$\begin{array}{c}\text { Block size } \\
\text { (1 falling block) } \\
\left(a_{1}\right)\end{array}$} & \multicolumn{2}{|c|}{$\begin{array}{c}\text { Rock volume } \\
\text { p1 falling } \\
\text { blocks) } \\
\left(\mathrm{a}_{2}\right)\end{array}$} & $\begin{array}{l}\text { Time spent at } \\
\text { slope toe by } \\
\text { machinery/ } \\
\text { workers (\%) } \\
\text { (b) }\end{array}$ & $\begin{array}{l}\text { Space occupied by } \\
\text { machinery/workers } \\
\text { vs. slope length (\%) } \\
\text { (c) }\end{array}$ & \multicolumn{2}{|c|}{$\begin{array}{l}\text { Position of machinery/ } \\
\text { workers } \\
\text { in relation to slope toe } \\
\text { (d) }\end{array}$} \\
\hline & $\begin{array}{c}<0.001 \mathrm{~m}^{3} \\
0.001-0.1 \mathrm{~m}^{3}\end{array}$ & 0.9 & $\begin{array}{l}<0.1 \mathrm{~m}^{3} \\
0.1-5 \mathrm{~m}^{3}\end{array}$ & $\begin{array}{c}1 \\
1.5 \\
\end{array}$ & \multirow{4}{*}{$\begin{array}{l}\text { Days/year } \\
\text { shifts/day } \\
\text { hours/shift } \\
\text { \% time under } \\
\text { slope }\end{array}$} & $\begin{array}{l}\text { Space occupied by } \\
\text { machine vs. slope length } \\
\left(\mathrm{c}_{\mathrm{mach}}\right)\end{array}$ & $\begin{array}{c}\text { Very close }\left(x^{\prime} H<10 \%\right) \\
\text { Close }\left(x^{\prime}|-|<25 \%\right)\end{array}$ & \\
\hline & $0.1-1 \mathrm{~m}^{3}$ & & $5-50 \mathrm{~m}^{3}$ & 2 & & \multirow{2}{*}{$\begin{array}{c}\text { Space occupled by } \\
\text { persons }(1 \mathrm{~m}) \mathrm{vs} \text {. slope } \\
\text { |ength (Cpers) }\end{array}$} & Average $(\mathrm{x} / \mathrm{H}<50 \%)$ & 0.1 \\
\hline & $>1 \mathrm{~m}^{3}$ & n.o & $>50 \mathrm{~m}^{3}$ & 2.5 & & & Far $\left(x^{\prime} H<100 \%\right)$ & 0.01 \\
\hline & & & & & & & ine & \\
\hline
\end{tabular}

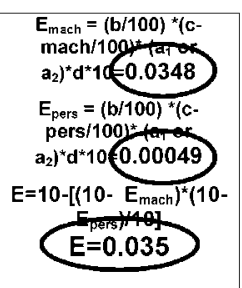

\begin{tabular}{|c|c|c|c|c|c|c|}
\hline \multirow{2}{*}{$\begin{array}{c}\text { SLOPE ROCKFALL HISTORY } \\
\text { No recorded } \\
\text { rockfalls }\end{array}$} & $\begin{array}{c}\text { Very few } \\
\text { rockfalls }\end{array}$ & $\begin{array}{c}\text { No data } \\
\text { Unreliable observations }\end{array}$ & $\begin{array}{c}\text { Occasional } \\
\text { rockfalls }\end{array}$ & $\begin{array}{c}\text { Several rockfalls } \\
\text { Nogacctannts }\end{array}$ & $\begin{array}{c}\text { Some rockfalls } \\
1 \text { reported accident }\end{array}$ & $\begin{array}{c}\text { Frequent rockfalls } \\
>1 \text { reported accident }\end{array}$ \\
\hline $\mathbf{0 . 7 5}$ & $\mathbf{0 . 9}$ & $\mathbf{1 . 0}$ & $\mathbf{1 . 1}$ & $\mathbf{1 . 2}$ & $\mathbf{1 . 4}$ & $\mathbf{1 . 5}$ \\
\hline
\end{tabular}

ROFRAQ $=(A \times B \times C \times D \times E \times F)=$

$\operatorname{ROFRAQ}_{\text {pers }}=\left(A \times B \times C \times D \times E_{\text {pers }} \times F\right)=$
$\operatorname{ROFRAQ}_{\mathrm{BASIC}}=(A \times B \times C \times D)=$

$\operatorname{ROFRAQ}_{\text {mach }}=\left(A \times B \times C \times D \times E_{\text {mach }} \times F\right)=$

Estimated probability of an accident due to rockfall occurring on the slope $=$ ROFRAQ $/ 100,000=$

\begin{tabular}{|c|c|c|c|c|c|}
\hline \multicolumn{6}{|c|}{ Preliminary assessment of the quarry fate hazard accordingto ROFRAQ results } \\
\hline Less than 10 & $10-25$ & $25-100$ & $100-250$ & $250-1000$ & More than 1000 \\
\hline $\begin{array}{l}\text { VERY LOW RISK } \\
\text { No special } \\
\text { measures required }\end{array}$ & $\begin{array}{c}\text { LOW RISK } \\
\text { Simple precautionary } \\
\text { measures required } \\
\text { (inc. regular } \\
\text { observation) }\end{array}$ & $\begin{array}{l}\text { LOW TO AVERAGE RISK } \\
\text { Some simple safety } \\
\text { precautions required e.g. } \\
\text { avoid traffic under slope } \\
\text { during rainy periods. efc. }\end{array}$ & $\begin{array}{l}\text { AVERAGE RISK } \\
\text { Important safety measures } \\
\text { required. Improve berms and }\end{array}$ & $\begin{array}{c}\text { HIGH RISK } \\
\text { Highly hazardous. } \\
\text { Redraft mining plan, } \\
\text { enlarge catch-benches, } \\
\text { redesign locally, etc. }\end{array}$ & $\begin{array}{l}\text { VERY HIGH RISK } \\
\text { Redesign quarry, } \\
\text { install meshes, build } \\
\text { ditches, etc. }\end{array}$ \\
\hline
\end{tabular}

Fig. 7. Completed ROFRAQ datasheet for Slope 1 in Quarry PO-01.

machine-by-machine basis, and a similar procedure was used for workers on foot. Table 2 summarises the data used to calculate a final value for $E$ of 0.03527 .

\subsubsection{Rating F. Quarry/slope rockfall history}

According to conversations with mine workers, a number of rockfalls for the slope had been observed in 


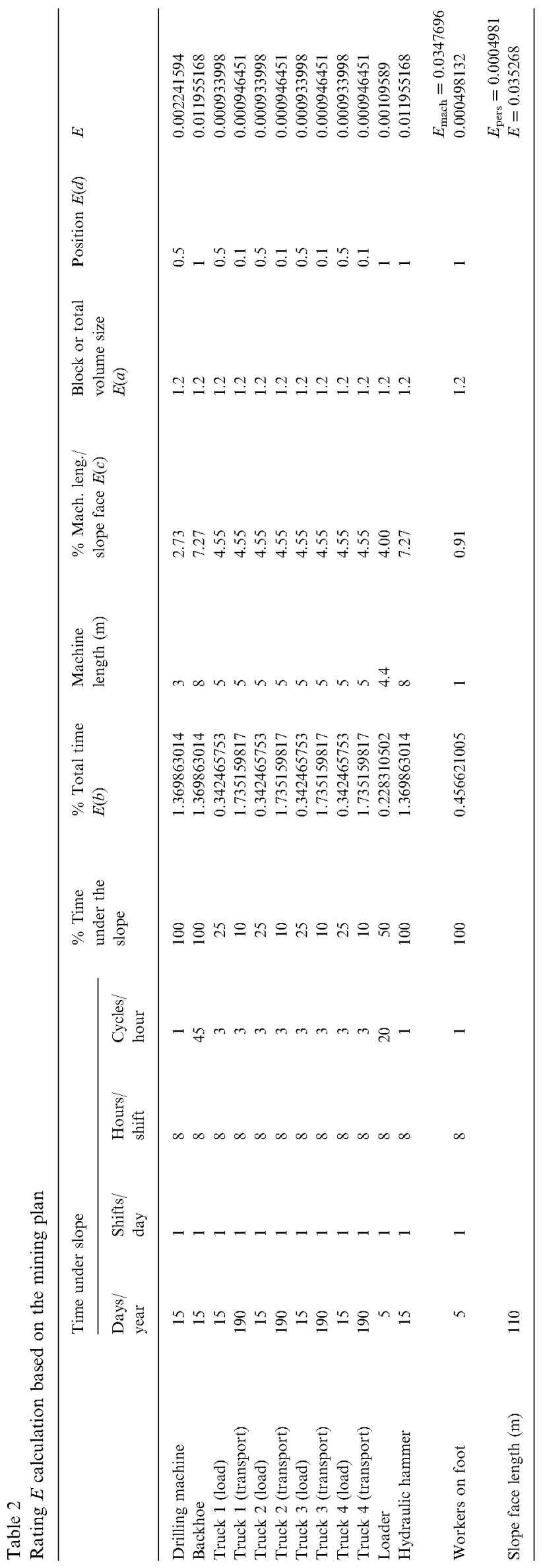

previous years, none of which resulted in accidents. Consequently, the value for rating $F$ was set at 1.2.

\subsubsection{ROFRAQ results and interpretation}

The final ROFRAQ value was obtained by multiplying all the ratings $A$ to $F$, resulting in a value of 171.48 , corresponding to a yearly probability of just over 0.0017 of an accident occurring as a consequence of a rockfall. This is a rather high value for a single slope face. On the basis of this preliminary assessment (see the final section of Fig. 7), a number of safety measurements need to be implemented, such as berm improvements, more bench cleanups, more control over blasting, etc.

In accordance with the work by Bunce and the modifications proposed by Hoek and given the probabilistic nature of the method, the information for the slope can be expressed in terms of an event tree analysis. An event tree, which can be created manually or using a code such as Precision Tree shows the probability of occurrence assigned to each event (link) in a sequence (chain) of events, the outcome of which might be a rockfall accident under the slope. This type of probabilistic approach underlies the structure of ROFRAQ, and according to the definition of ROFRAQ, the probability of each event occurring can be obtained in percentage terms by multiplying the values for ratings $A$ to $E$ by 10 . Rating $F$, which reflects the slope rockfall history, can be understood as a factor of safety.

Fig. 8 shows the event tree analysis of the likelihood of a rockfall on Slope 1 of the granite aggregate quarry. In order to calculate the probability of a fatality due to a rockfall on Slope 1, the percentage of accidents leading to fatalities is needed to know, which according to ANEFA [7], is around $25 \%$, i.e., one in four accidents result in a fatality. An extension of this accident/fatality probability analysis to the whole quarry, the province and the country is discussed below.

\subsection{Remedial measures for Slope 1}

In order to reduce the high risk level for Slope 1, it was proposed to put a bed of gravel and sand at the bottom of this slope and to leave a $35^{\circ}$-angle trench on both the south and north sides of the road. The Rocfall code indicates that, as a consequence, the percentage of blocks falling from the slope and reaching the road would drop from $100 \%$ to $4 \%$ (see Fig. $9 \mathrm{~b}$ and c). Fig. $9 \mathrm{~b}$ and the detail corresponding to this same simulation in Fig. 9c are a clear evidence of the beneficial role played by the sand in this particular analysis. Rating $D$ in the ROFRAQ classification would accordingly drop from 10 to 0.4 , representing a much reduced risk level.

This solution was not implemented, however, as the risk level was greatly lowered in the following years when rock transport was first largely rerouted to a new road and then eventually eliminated entirely along this route. 


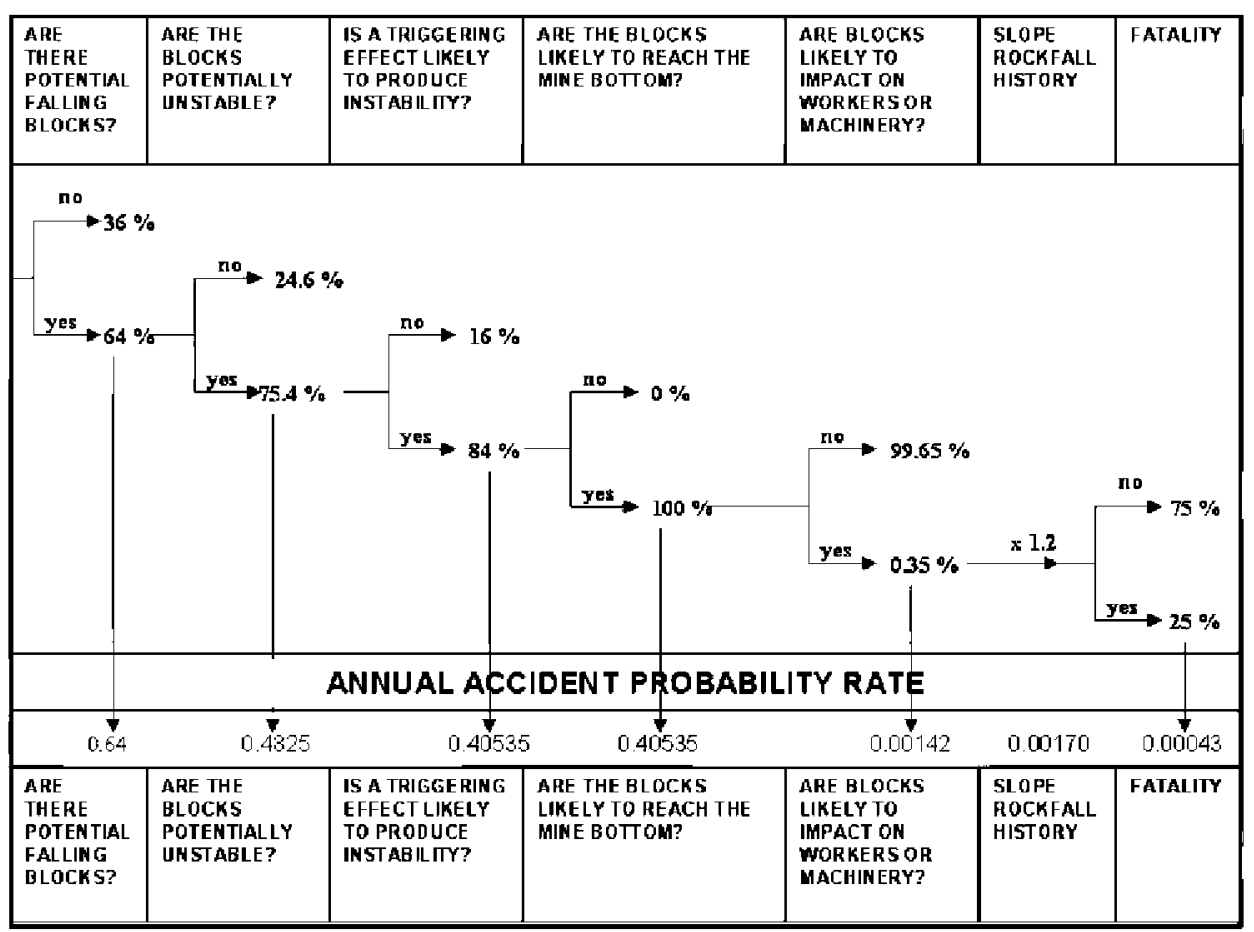

Fig. 8. Event tree analysis for potential Slope 1 rockfalls, based on ROFRAQ estimates (adapted from Bunce [44] and Hoek [32]).

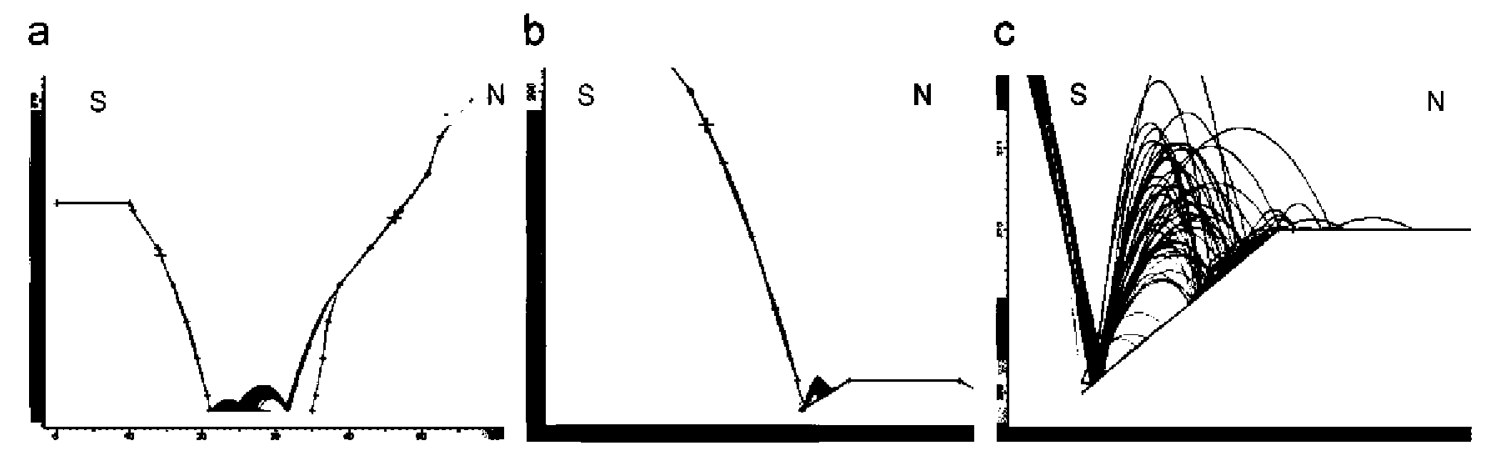

Fig. 9. (a) RocFall model of Slopes 1 (S) and 15 (N). (b) RocFall model of Slope 1 with a sand bed at the toe. (c) RocFall simulation detail for 9 (b).

\subsection{Four-year ROFRAQ evolution}

The methodology described above was applied to all the slopes in the studied quarry for the period 2002-2005. The ROFRAQ values obtained are summarised in Table 3.

In 2002, only two slopes ( 1 and 15) showed a preliminary assessment of the quarry face hazard according ROFRAQ results over the recommended guidelines, and both had average risk values. These ROFRAQ values were associated with the fact that most rock was transported in the year in question through the trench between these two slopes. This fact, combined with the fact that the slopes were prone to rockfalls, produced a high value for the very sensitive $E$ rating, which was reflected in the overall ROFRAQ value.

In 2003, three slopes (1,6 and 12) had an average risk value. Slope 1 continued to have a ROFRAQ rating of above 100 , despite the fact that transport was largely rerouted to a new access ramp. Slope 6 had a ROFRAQ value of close to 100 (the cutoff point above which safety measurements were recommended). This was due to footwall slope instability resulting from a joint set (No. 3) lying parallel to the bench faces, which in turn resulted in overblasting and local instabilities in the area (Fig. 10). In 2003, Slope 12 had a ROFRAQ value of 240 - the highest ever recorded in the quarry - explained by the occurrence of block toppling (Fig. 11) in an area densely populated by mining machinery. As a remedial measure, the slope was gradually remade by pushing it backwards, a task which was included in the mining plans for 2004 and 2005. To further reduce rockfall-related risk, Slopes 11 and 12 were reshaped into a new slope with an improved orientation (Slope 10').

In 2004 and 2005, rockfall hazard was relatively low as there were no slopes with a ROFRAQ value of above 100 . This situation only required the application of simple precautionary measures (such as avoiding particular slopes in rainy periods when the danger of a rockfall was greater). 
Table 3

ROFRAQ values for all slopes in Quarry PO-01 for the period 2002 to 2005

ROFRAQ - granite aggregate quarry PO-01

\begin{tabular}{|c|c|c|c|c|c|c|c|c|c|c|c|c|c|}
\hline \multirow[t]{2}{*}{ Slope } & \multirow[t]{2}{*}{ Year } & \multirow[t]{2}{*}{$A$} & \multirow[t]{2}{*}{$B$} & \multirow[t]{2}{*}{$C$} & \multirow[t]{2}{*}{$D$} & \multicolumn{3}{|l|}{$E$} & \multirow[t]{2}{*}{$F$} & \multirow[t]{2}{*}{ ROFRAQ $_{\text {BASIC }}$} & \multirow[t]{2}{*}{ ROFRAQ $_{\text {mach }}$} & \multirow[t]{2}{*}{ ROFRAQ $Q_{\text {pers }}$} & \multirow[t]{2}{*}{ ROFRAQ } \\
\hline & & & & & & $E_{\text {mach }}$ & $E_{\text {pers }}$ & $E$ & & & & & \\
\hline 1 & 2002 & 6.40 & 7.54 & 8.40 & 10.00 & 0.034770 & 0.000498 & 0.035264 & 1.20 & 40.52 & 169.07 & 2.42 & 171.48 \\
\hline 2 & 2002 & 1.28 & 3.97 & 8.10 & 10.00 & 0.076164 & 0.000250 & 0.076412 & 0.90 & 4.10 & 28.8 & 0.09 & 28.18 \\
\hline 3 & 2002 & 1.28 & 2.54 & 8.10 & 10.00 & 0.051272 & 0.001565 & 0.052829 & 0.90 & 2.62 & 12.11 & 0.37 & 12.48 \\
\hline 4 & 2002 & 2.00 & 4.28 & 7.70 & 3.00 & 0.010685 & 0.000433 & 0.011117 & 0.90 & 1.98 & 1.90 & 0.08 & 1.98 \\
\hline 5 & 2002 & 3.80 & 6.31 & 7.90 & 3.50 & 0.124956 & 0.002491 & 0.127416 & 1.10 & 6.62 & 91.06 & 1.81 & 92.85 \\
\hline 6 & 2002 & 3.60 & 6.04 & 8.00 & 2.50 & 0.102348 & 0.001957 & 0.104285 & 1.10 & 4.35 & 48.98 & 0.94 & 49.91 \\
\hline 7 & 2002 & 3.60 & 6.33 & 8.40 & 2.00 & 0.035323 & 0.001957 & 0.037273 & 1.10 & 3.83 & 14.88 & 0.82 & 15.70 \\
\hline 8 & 2002 & 3.60 & 4.64 & 8.00 & 2.00 & 0.037808 & 0.002740 & 0.040538 & 1.10 & 2.67 & 11.12 & 0.81 & 11.92 \\
\hline 9 & 2002 & 7.20 & 4.02 & 8.40 & 3.00 & 0.094700 & 0.003040 & 0.097688 & 1.20 & 7.29 & 82.89 & 2.66 & 85.50 \\
\hline 11 & 2002 & 3.60 & 4.64 & 8.00 & 2.00 & 0.018904 & 0.002740 & 0.021639 & 1.10 & 2.67 & 5.56 & 0.81 & 6.36 \\
\hline 12 & 2002 & 7.60 & 7.60 & 8.70 & 9.00 & 0.006697 & 0.002435 & 0.009131 & 1.20 & 45.23 & 36.35 & 13.22 & 49.55 \\
\hline 13 & 2002 & 4.80 & 5.45 & 8.30 & 10.00 & 0.020320 & 0.000913 & 0.021231 & 0.90 & 21.69 & 39.67 & 1.78 & 41.45 \\
\hline 14 & 2002 & 4.80 & 6.12 & 8.30 & 10.00 & 0.008371 & 0.001522 & 0.009892 & 1.20 & 24.37 & 24.48 & 4.45 & 28.93 \\
\hline 15 & 2002 & 5.80 & 6.82 & 8.00 & 10.00 & 0.059203 & 0.000498 & 0.059698 & 1.10 & 31.64 & 206.02 & 1.73 & 207.74 \\
\hline 1 & 2003 & 6.40 & 7.54 & 7.40 & 10.00 & 0.026526 & 0.001096 & 0.027618 & 1.20 & 35.71 & 113.67 & 4.70 & 118.35 \\
\hline 2 & 2003 & 4.20 & 3.97 & 6.60 & 7.50 & 0.033096 & 0.001096 & 0.034188 & 1.00 & 8.25 & 27.30 & 0.90 & 28.20 \\
\hline 3 & 2003 & 2.45 & 2.54 & 6.60 & 6.00 & 0.057534 & 0.001565 & 0.059091 & 1.00 & 2.46 & 14.18 & 0.39 & 14.56 \\
\hline 4 & 2003 & 3.15 & 3.91 & 6.60 & 4.00 & 0.038116 & 0.001154 & 0.039266 & 1.00 & 3.25 & 12.39 & 0.38 & 12.77 \\
\hline 5 & 2003 & 3.80 & 6.31 & 7.90 & 3.50 & 0.035604 & 0.002491 & 0.038086 & 1.10 & 6.62 & 25.95 & 1.81 & 27.75 \\
\hline 6 & 2003 & 3.60 & 6.04 & 8.00 & 3.50 & 0.194200 & 0.001960 & 0.196146 & 1.10 & 6.09 & 130.12 & 1.31 & 131.42 \\
\hline 7 & 2003 & 3.60 & 6.33 & 8.40 & 2.00 & 0.067906 & 0.001957 & 0.069850 & 1.10 & 3.83 & 28.61 & 0.82 & 29.42 \\
\hline 8 & 2003 & 3.60 & 4.64 & 8.00 & 2.00 & 0.014247 & 0.002740 & 0.016982 & 1.10 & 2.67 & 4.19 & 0.81 & 4.99 \\
\hline 9 & 2003 & 7.20 & 4.02 & 8.40 & 6.00 & 0.010781 & 0.000521 & 0.011302 & 1.20 & 14.59 & 18.87 & 0.91 & 19.78 \\
\hline 11 & 2003 & 3.60 & 4.64 & 8.00 & 2.00 & 0.076104 & 0.002740 & 0.078822 & 1.10 & 2.67 & 22.37 & 0.81 & 23.17 \\
\hline 12 & 2003 & 7.60 & 7.60 & 8.70 & 9.00 & 0.042846 & 0.001522 & 0.044362 & 1.20 & 45.23 & 232.53 & 8.26 & 240.76 \\
\hline 13 & 2003 & 4.00 & 3.76 & 6.60 & 5.00 & 0.013699 & 0.001096 & 0.014793 & 1.00 & 4.96 & 6.80 & 0.54 & 7.34 \\
\hline 14 & 2003 & 4.80 & 6.12 & 8.30 & 10.00 & 0.008371 & 0.001522 & 0.009892 & 1.20 & 24.37 & 24.48 & 4.45 & 28.93 \\
\hline 15 & 2003 & 5.80 & 6.82 & 8.00 & 10.00 & 0.018680 & 0.000498 & 0.019177 & 1.10 & 31.64 & 65.00 & 1.73 & 66.73 \\
\hline 1 & 2004 & 6.40 & 7.54 & 7.40 & 10.00 & 0.020939 & 0.000498 & 0.021436 & 1.20 & 35.71 & 89.73 & 2.13 & 91.86 \\
\hline 2 & 2004 & 4.20 & 3.97 & 6.60 & 7.50 & 0.012603 & 0.000250 & 0.012852 & 1.00 & 8.25 & 10.39 & 0.21 & 10.60 \\
\hline 3 & 2004 & 2.45 & 2.54 & 6.60 & 6.00 & 0.046967 & 0.001565 & 0.048525 & 1.00 & 2.46 & 11.57 & 0.39 & 11.96 \\
\hline 4 & 2004 & 3.15 & 3.91 & 6.60 & 4.00 & 0.067466 & 0.001154 & 0.068611 & 1.00 & 3.25 & 21.94 & 0.38 & 22.31 \\
\hline 5 & 2004 & 5.00 & 6.31 & 7.00 & 3.50 & 0.009773 & 0.001826 & 0.011598 & 1.00 & 7.72 & 7.55 & 1.41 & 8.96 \\
\hline 6 & 2004 & 4.50 & 6.00 & 7.00 & 3.50 & 0.068000 & 0.001826 & 0.069814 & 1.00 & 6.62 & 45.00 & 1.21 & 46.20 \\
\hline 7 & 2004 & 4.25 & 3.73 & 6.60 & 6.50 & 0.050274 & 0.001096 & 0.051364 & 1.00 & 6.80 & 34.19 & 0.75 & 34.93 \\
\hline 8 & 2004 & 7.25 & 4.37 & 6.80 & 3.50 & 0.015799 & 0.001826 & 0.017623 & 1.00 & 7.54 & 11.92 & 1.38 & 13.29 \\
\hline 9 & 2004 & 5.25 & 3.90 & 7.00 & 7.00 & 0.046874 & 0.001992 & 0.048857 & 1.00 & 10.04 & 47.07 & 2.00 & 49.06 \\
\hline $10^{\prime}(11+12)$ & 2004 & 6.00 & 5.35 & 7.40 & 6.00 & 0.054521 & 0.000250 & 0.054769 & 1.20 & 14.24 & 93.18 & 0.43 & 93.61 \\
\hline 13 & 2004 & 4.00 & 3.76 & 6.60 & 5.00 & 0.004274 & 0.001096 & 0.005369 & 1.00 & 4.96 & 2.12 & 0.54 & 2.66 \\
\hline 14 & 2004 & 5.60 & 6.71 & 7.20 & 10.00 & 0.010046 & 0.001826 & 0.011870 & 1.20 & 27.06 & 32.62 & 5.93 & 38.54 \\
\hline 15 & 2004 & 5.80 & 6.82 & 7.00 & 10.00 & 0.019863 & 0.000250 & 0.020113 & 1.20 & 27.68 & 65.98 & 0.83 & 66.81 \\
\hline 1 & 2005 & 6.40 & 7.54 & 7.40 & 10.00 & 0.006351 & 0.000498 & 0.006849 & 1.20 & 35.71 & 27.22 & 2.13 & 29.35 \\
\hline 2 & 2005 & 2.70 & 4.57 & 6.60 & 3.00 & 0.006700 & 0.001220 & 0.007914 & 1.00 & 2.44 & 1.64 & 0.30 & 1.93 \\
\hline 3 & 2005 & 2.45 & 2.54 & 6.60 & 6.00 & 0.042270 & 0.001565 & 0.043829 & 1.00 & 2.46 & 10.42 & 0.39 & 10.80 \\
\hline 4 & 2005 & 3.15 & 3.91 & 6.60 & 4.00 & 0.022350 & 0.001154 & 0.023501 & 1.00 & 3.25 & 7.27 & 0.38 & 7.64 \\
\hline 5 & 2005 & 5.00 & 6.31 & 7.00 & 3.50 & 0.026899 & 0.001992 & 0.028886 & 1.00 & 7.72 & 20.78 & 1.54 & 22.31 \\
\hline 6 & 2005 & 4.50 & 6.00 & 7.00 & 3.50 & 0.014384 & 0.001826 & 0.016207 & 1.00 & 6.62 & 9.52 & 1.21 & 10.73 \\
\hline 7 & 2005 & 6.75 & 4.67 & 6.60 & 4.00 & 0.063147 & 0.001565 & 0.064702 & 1.20 & 8.33 & 63.08 & 1.56 & 64.64 \\
\hline 8 & 2005 & 9.25 & 7.61 & 6.80 & 5.50 & 0.011311 & 0.000783 & 0.012093 & 1.00 & 26.31 & 29.76 & 2.06 & 31.82 \\
\hline 9 & 2005 & 5.25 & 3.90 & 7.00 & 7.00 & 0.028521 & 0.000783 & 0.029301 & 1.00 & 10.04 & 28.64 & 0.79 & 29.42 \\
\hline $10^{\prime}(11+12)$ & 2005 & 5.00 & 6.10 & 7.20 & 6.00 & 0.010904 & 0.002192 & 0.013093 & 1.20 & 13.18 & 17.25 & 3.47 & 20.72 \\
\hline 13 & 2005 & 4.75 & 6.07 & 6.60 & 3.25 & 0.002411 & 0.002192 & 0.004602 & 1.00 & 6.18 & 1.49 & 1.36 & 2.85 \\
\hline 14 & 2005 & 5.60 & 6.71 & 7.20 & 10.00 & 0.004018 & 0.001826 & 0.005844 & 1.20 & 27.06 & 13.05 & 5.93 & 18.97 \\
\hline 15 & 2005 & 5.80 & 7.53 & 7.00 & 10.00 & 0.006351 & 0.000548 & 0.006899 & 1.10 & 30.55 & 21.35 & 1.84 & 23.19 \\
\hline
\end{tabular}




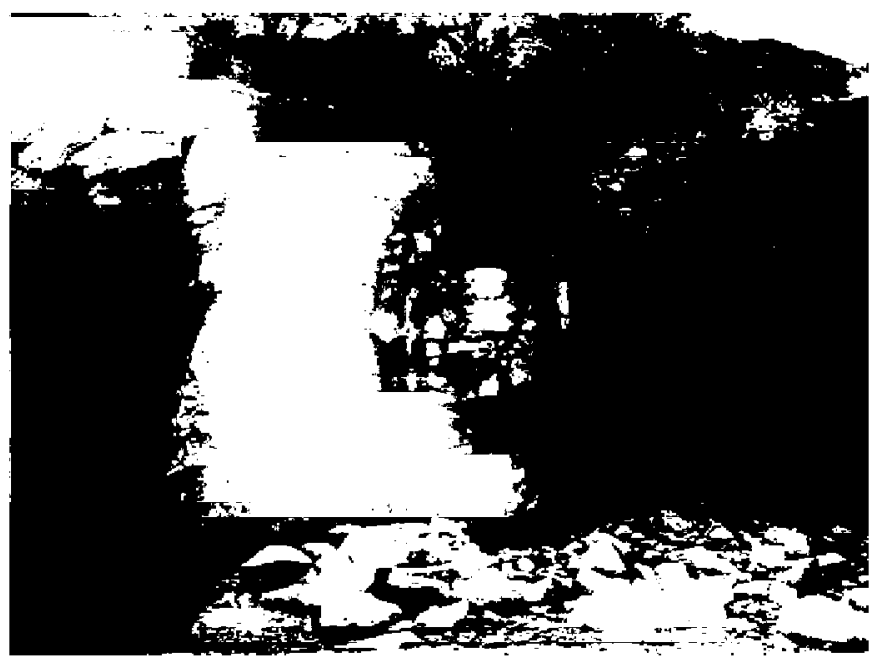

Fig. 10. Photograph of a bench in Slope 6: ROFRAQ value of over 100 in 2003.

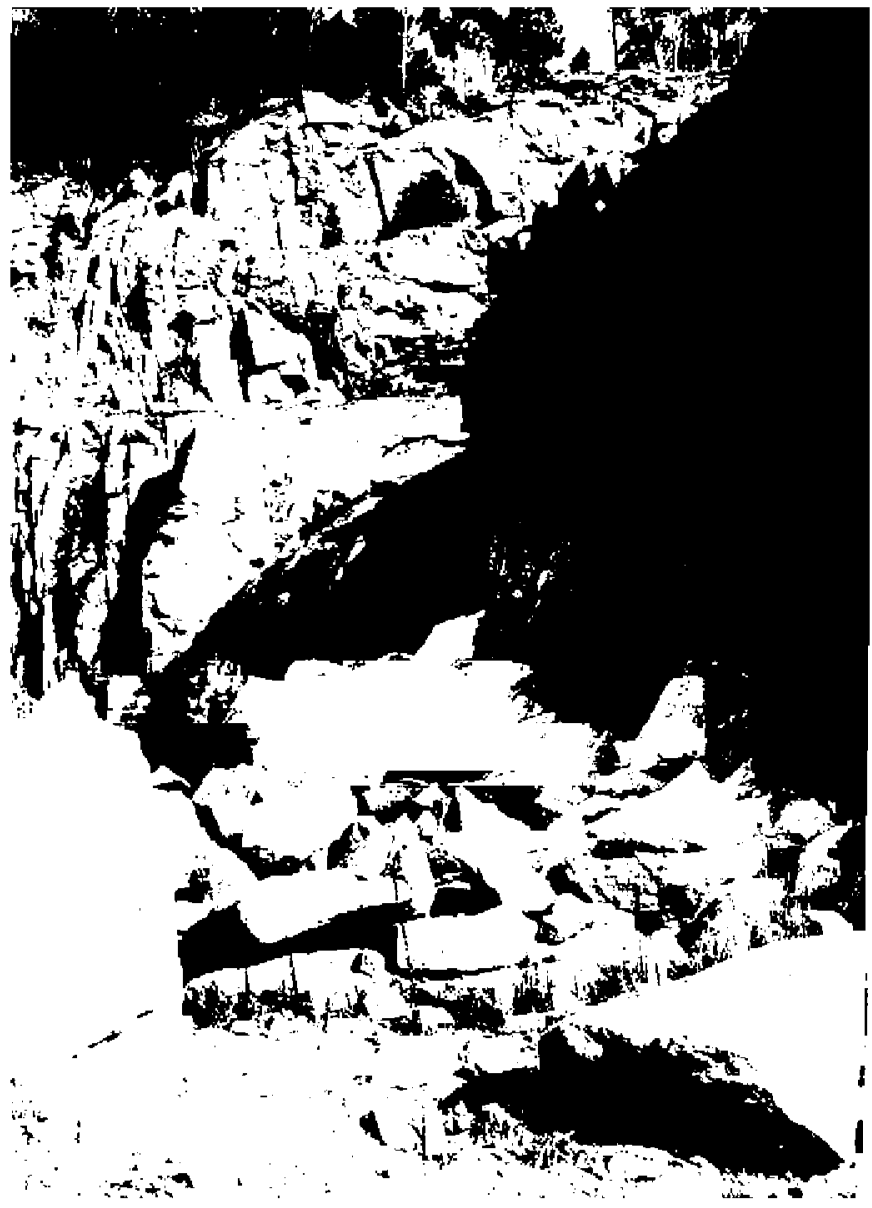

Fig. 11. Photograph of a bench in Slope 12: ROFRAQ value of 240 in 2003.

\subsection{Hazard assessment in Quarry PO-01: final considerations}

The data for the ROFRAQ appraisal for Quarry PO-01 for the period 2002-2005 are presented in graph form in
Fig. 12. As already mentioned, only four slopes requiring remedial measures (average risk cases) were detected in the quarry during the study period. In the authors' experience, the occurrence of average-risk slopes, which is not unusual, is typically associated with the concentration of extraction or transportation activities in areas of the quarries where instabilities are common. However, it is important to identify these areas (using ROFRAQ or a similar method) and to implement simple, inexpensive remedial measures to mitigate risk during operations in these zones.

Of the analysed slopes, two-thirds were rated as low or very low risk slopes and so rockfall accidents are unlikely; the other one-third were rated as having low-to-average risk levels. These slopes do not require specific safety measures, but taking a longer-term view, it is advisable to avoid increasing risk (i.e., the ROFRAQ value) in subsequent years, and, in daily mining operations, to limit production in these areas during wet or cold periods.

Using ROFRAQ, it is possible to reasonably estimate, and therefore control, the expected accident rate due to rockfall. Thus, Fig. 12 shows that, in 2002, there were two slopes rated as average risk and seven slopes rated as lowto-average risk, but in 2005 , there were no average risk slopes and only four low-to-average risk slopes. This improvement in the rockfall accident ratings is also illustrated in Fig. 13, which shows how the mean ROFRAQ value for the quarry as a whole gradually fell over the study period.

With the aim of obtaining information on rockfall risk for input to future mining plans for the quarry, ROFRAQ all the slopes for all the years of the study. ROFRAQ ${ }_{\text {BASIC }}$ is an estimate of the likelihood of a slope releasing rocks and does not take into account the presence of machines or workers on the slopes. It acts as an indicator of slopes that will be potentially hazardous if activity is concentrated in the vicinity. When designing the mining plan, rockfall risk for these slopes can be mitigated by providing for limited mining activity and/or by enlarging catch-benches.

The data in Fig. 14, for example, indicated the advisability of avoiding major mining operations or transport routes under Slopes 1, 8, 14 and 15 in 2005, because of their likelihood of releasing rocks. This graph also demonstrates how the reorientation and reshaping of Slopes 11 and 12 into Slope $10^{\prime}$ made the area much safer from a rockfall-risk perspective.

The value of ROFRAQ for a slope divided by 100,000 is an estimate of the probability of an accident. 1 minus this value is, therefore, the probability of no accident. Multiplying the non-accident probabilities for all the slopes in a quarry, the non-accident probability for the whole quarry is obtained. Again, 1 minus this value would be an estimate of the probability of an accident in the quarry. These calculations for the years 2002, 2003, 2004 and 2005 produced values of $0.0081,0.0073,0.0045$ and 0.0027 , respectively, or $0.81,0.73,0.45$ and 0.27 in percentage terms. In accident terms, these values represent between 


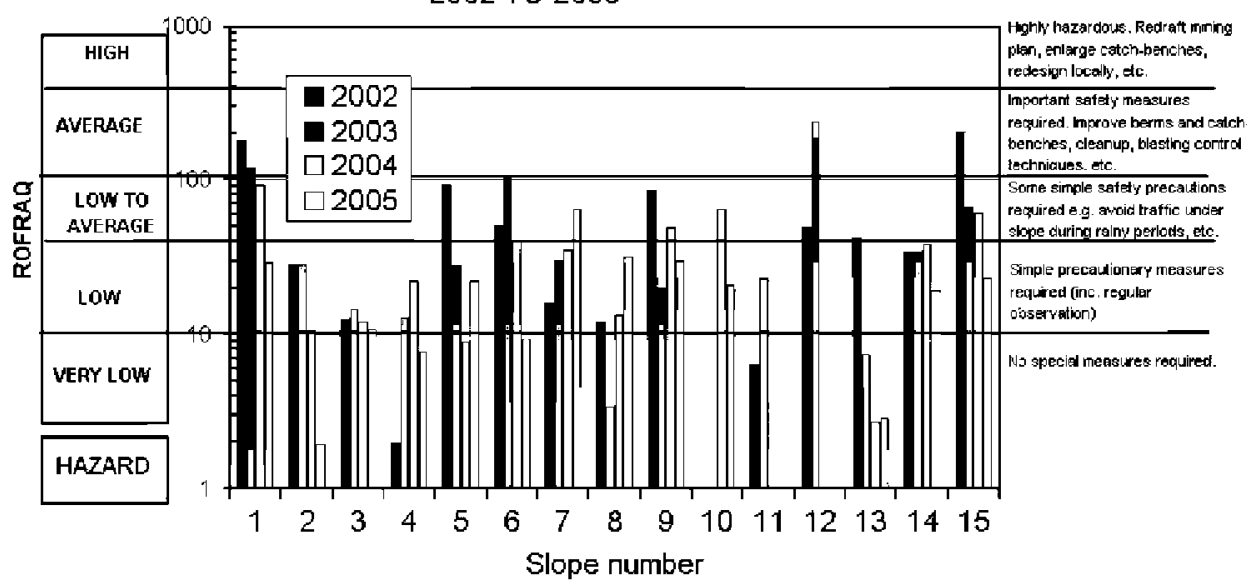

Fig. 12. ROFRAQ results for Quarry PO-01 slopes for the period 2002-2005.

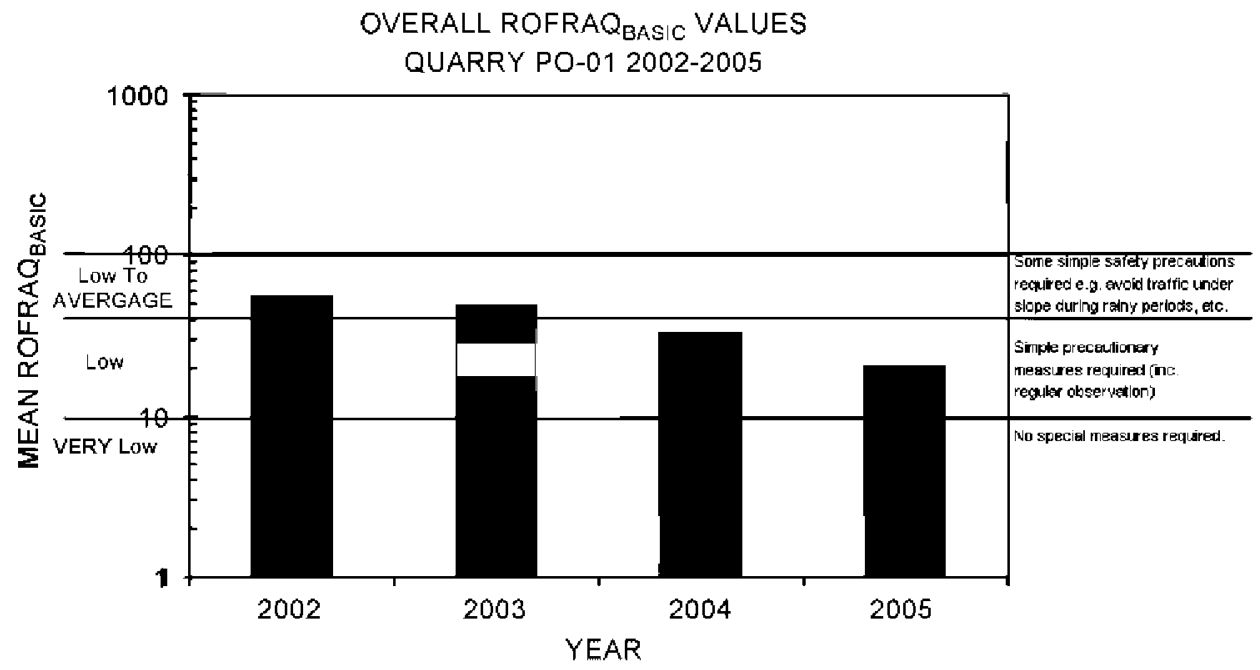

Fig. 13. Mean ROFRAQ ${ }_{\text {BASIC }}$ value for Quarry PO-01 for the period 2002-2005.

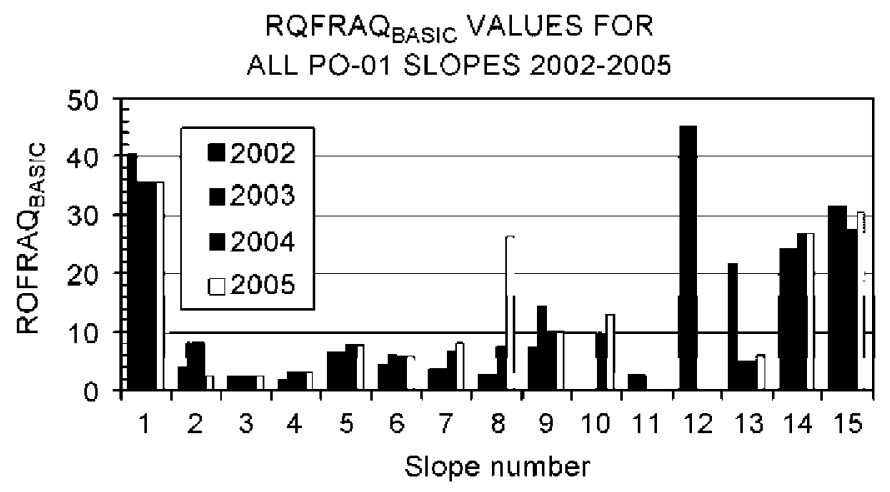

Fig. 14. ROFRAQ ${ }_{B A S I C}$ values for Quarry PO-01 slopes for the period $2002-2005$.

three and eight accidents per 1000 years, which can be considered as a reasonably safe statistic. According to ANEFA data 1 fatality can be expected per four accidents, given the length of the machines. Therefore, dividing the accident probability figures by 4 , an annual probability of a fatality of between 0.002 and 0.0006 is obtained.

According to Nielsen et al. a proposed guideline for tolerable risk in the case of dam failures would be an annual probability of fatalities of 0.001 . Hoek considered this value directly applicable to rock slopes on highways, which are major civil engineering structures that involve risks to the public. For the case of quarries, where the question of the general public is irrelevant, this figure is rather strict; the authors are of the opinion that a tolerable risk level would be in the region of 0.005 , a guideline that is met by Quarry PO-01. Nonetheless, it is important to point out that, in view of the large number of aggregate quarries in developed countries, an effort to lower the average risk level would contribute greatly to reducing fatalities.

In the province of Pontevedra (NW Spain) alone, there are about 25 aggregate or mineral deposits. On the basis of the results for Quarry PO-01, let us assume an accident probability rate of 0.0005 for every six quarries. 
Calculating the total annual probability of accidents for this region, a value of $12.7 \%$ is obtained. This value correlates reasonably well with the data presented by Rey

who observed two accidents for a control period of 18 years. If this calculation was extended to the whole of Spain, which has around 1000 hard rock quarries and open pit mines, it would be obtained a probability value for rockfall accidents of $99.66 \%$. This value is not surprising taking into account that 35 rockfall-related fatalities were recorded for Spain for the period 1987-1995 This may seem to be fighting with the detail considered in the ROFRAQ calculation, but the authors just want to show that the big numbers are consistent with their results.

These data indicate that the ROFRAQ estimated risk level is of the same order of magnitude as accidents recorded in practice, which would highlight the fact that an effective rockfall control method, based on, for instance, a technical assessment tool like ROFRAQ, would help assess the probability of rockfall-related accidents and, in turn, lead to a reduction in accident rates.

\section{ROFRAQ application to other quarries and comparison with other methods}

ROFRAQ ${ }_{B A S I C}$ was also applied to quarries containing different sedimentary, metamorphic and igneous rocks (schist, limestone, granodiorite, slate and quartz). In order to compare results, the RHRS [9] and RHRON [10,11] methods were applied to the same slopes as ROFRAQ Since RHRS and RHRON were designed for application to roads, certain adaptations had to be made (commented below), in order to make a comparison with ROFRAQ possible.

What follows is an endeavour to perform a first validation of ROFRAQ. Nonetheless, in line with Starfield and Cundall [47], it has to be conceded that it is the issue of validation in a discipline such as rock mechanics is a moot one, as the discipline deals with natural materials (rock masses), each with its own particular idiosyncrasies, which is why the authors prefer to assess their method in relation to other similar methods. True validation would require several years of practical application and would, ultimately, rely on a wide consensus among users as to procedures and range of uses.

\subsection{RHRS and RHRON}

RHRS and RHRON were designed to assess rockfall hazard in roads and highways, and so take traffic under the slopes into account. For the sake of comparing results with ROFRAQBASIC, basic or primary versions of these methods were defined that excluded all ratings corresponding to traffic. These forms of RHRS and RHRON-defined exclusively for use in this researchonly assess a slope's ability to release rocks. Since the essential difference between ROFRAQ and RHRS or RHRON is in regard to the traffic under the slopes, the results for the basic forms of these three methods should, in theory, correlate well.

The adapted version of the RHRS, denominated

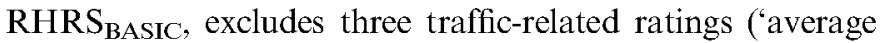
vehicle risk', 'percent of decision sight distance' and 'roadway width'). Furthermore, so that the retention capacities of catch-benches could be taken into account, the rating corresponding to 'ditch effectiveness' was more broadly considered as 'slope effectiveness'. Table 4, which is based on the original table in [9] (with the above-mentioned ratings excluded), summarises the score for the categories included in this basic classification. On the basis of a maximum score

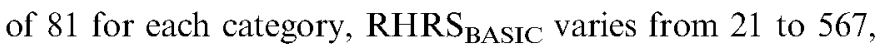
whereas RHRS in its original form takes values from 30 to 810 , so it could be inconsistent to use this basic version of RHRS for applications other than that described here.

Likewise, the adapted RHRON, which will be referred to

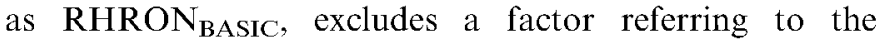
consequences of a rockfall (i.e., how it affects traffic on the road). The original RHRON is calculated by answering four basic questions, corresponding to the factors described in Table 5. Each factor is rated on a scale from 0 (good) to 9 (bad). The final value for RHRON is calculated as:

$\mathrm{RHRON}=\frac{F_{1}+F_{2}+F_{3}+F_{4}}{4}$.

A slope with a RHRON value of 0 is very safe and one rated 9 is very unsafe. The factors are estimated by averaging of a series of sub-factors. $F_{4}$, which is the factor related to consequences, is estimated by taking into account 'average vehicle risk', 'posted speed limit' and 'available paved width'. Obviously, to define a basic version of RHRON that suits authors' purposes, this 4th factor is excluded from

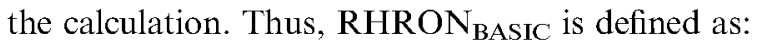

$\operatorname{RHRON}_{\text {BASIC }}=\frac{F_{1}+F_{2}+F_{3}}{3}$.

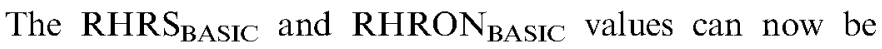
estimated for the same slopes for which the ROFRAQ $\mathrm{BASIC}$ values were obtained. In this way, results can be compared and correlations can be established.

\subsection{ROFRAQ $Q_{B A S I C}$ vs. $R H R S_{B A S I C}$ vs. RHRON $N_{B A S I C}$}

Quarry PO-01 slopes for 2005 and the riskier slopes for 2002-2004-a total of 18 slopes which had been previously evaluated using ROFRAQ - were evaluated using RHRS $_{\text {BASIC }}$ and RHRON BASIC. $_{\text {. }}$

In order to obtain further data to test and compare the proposed method, five new quarries and mines were studied from a rockfall hazard perspective. The selected slopes (39 in number) were rated using ROFRAQBASIC,

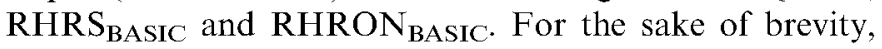
descriptive details are briefly summarised as follows:

- OU-01 (Fig. 15a) is an aggregate schist quarry with an annual production of 250,000 tons and with eight 
Table 4

Adapted Rockfall Hazard Rating System (RHRS BAsIC $_{\text {) }}$

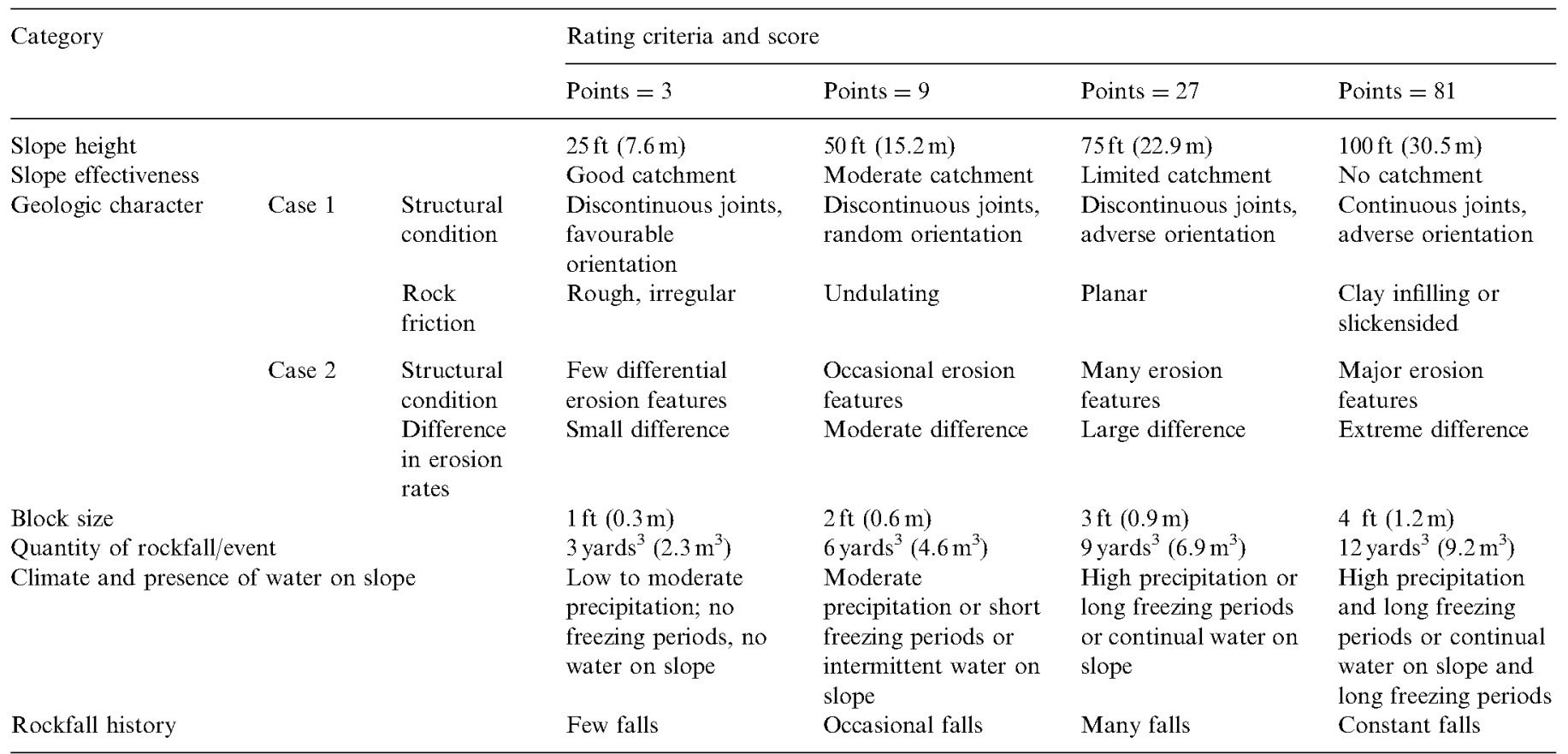

Based on Pierson et al.

Table 5

Ontario Rock Hazard Rating (RHRON)

\begin{tabular}{lll}
\hline Name Factor & Questions to be answered \\
\hline F1 & Magnitude & How much rock is unstable? \\
F2 & Instability & How soon or often is it likely to come down? \\
F3 & Reach & What are the chances of this rock reaching the \\
F4 & Consequences & How serious are the consequences of the blockage?
\end{tabular}

Source: Franklin and Senior and Senior

benches, $15-19 \mathrm{~m}$ high, carved into the mountain. Maximum slope height is $140 \mathrm{~m}$, and slope gradients are, on average, $52^{\circ}$. For this quarry, 12 slopes were analysed.

- LU-01 (Fig. 15b) is a limestone quarry of complex geology (very folded strata) in an early stage of development. For this quarry with a low rockfall hazard level, nine slopes were analysed.

- OU-02 (Fig. 15c) is an aggregate granodiorite quarry, with three $12-\mathrm{m}$ benches carved into the rock mass in order to extract around 300,000 tons of construction aggregates per year. For our purposes, eight slopes were analysed.

- BI-01 (Fig. 15d) is a roofing slate mine with an annual production of around 500,000 tons of raw mineral. The geology is complex, and different types of instability mechanisms including a pervasive tendency to topple in a wide area-have been identified. Rockfall phenomena are very visible on the quarry slopes. In this mine, four of the most dangerous slopes were assessed.

- CO-01 is a quartz mine with a 50-m-wide seam that produces some 400,000tons of raw mineral. Good quality quartz is sent to the silicon-metal and ferrosilicon industries, and the rest is sold as white aggregate. Some important faults in the deposit represent hazardous rockfall areas. This elongated mine was divided into six slopes for analysis purposes.

The database thus consisted of a total of 57 slopes from six quarries (representing different types of rocks and conditions) for which the ROFRAQ ${ }_{\text {BASIC, }}$ RHRS $_{\text {BASIC }}$

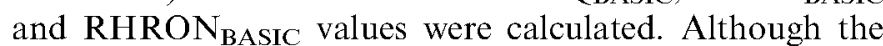
authors believe this data set to be large enough for this initial assessment, is planned to augment it further in the near future.

Fig. 16 shows how, for the 57 slopes, a trend is established for the data, which falls between the two broken lines. The data represent slopes identified according to quarry and assessed using only ROFRAQBASIC and

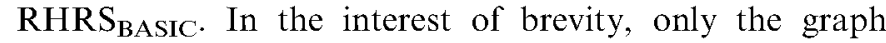
representing a comparison of $R O F R A Q_{B A S I C}$ with one of the other methods is reproduced, namely, RHRS BASIC. It can be observed that the data for some quarries are more scattered (e.g., PO-01), whereas those for other quarries tend to be more uniform (e.g., LU-01).

Figs. 17 and 18 show correlations, for all 57 slopes studied, between the quarry rockfall proposed method

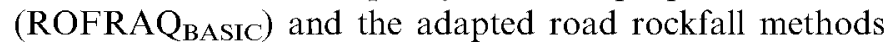
(RHRS BASIC and RHRON $_{\text {BASIC }}$ ). A logarithmic line 

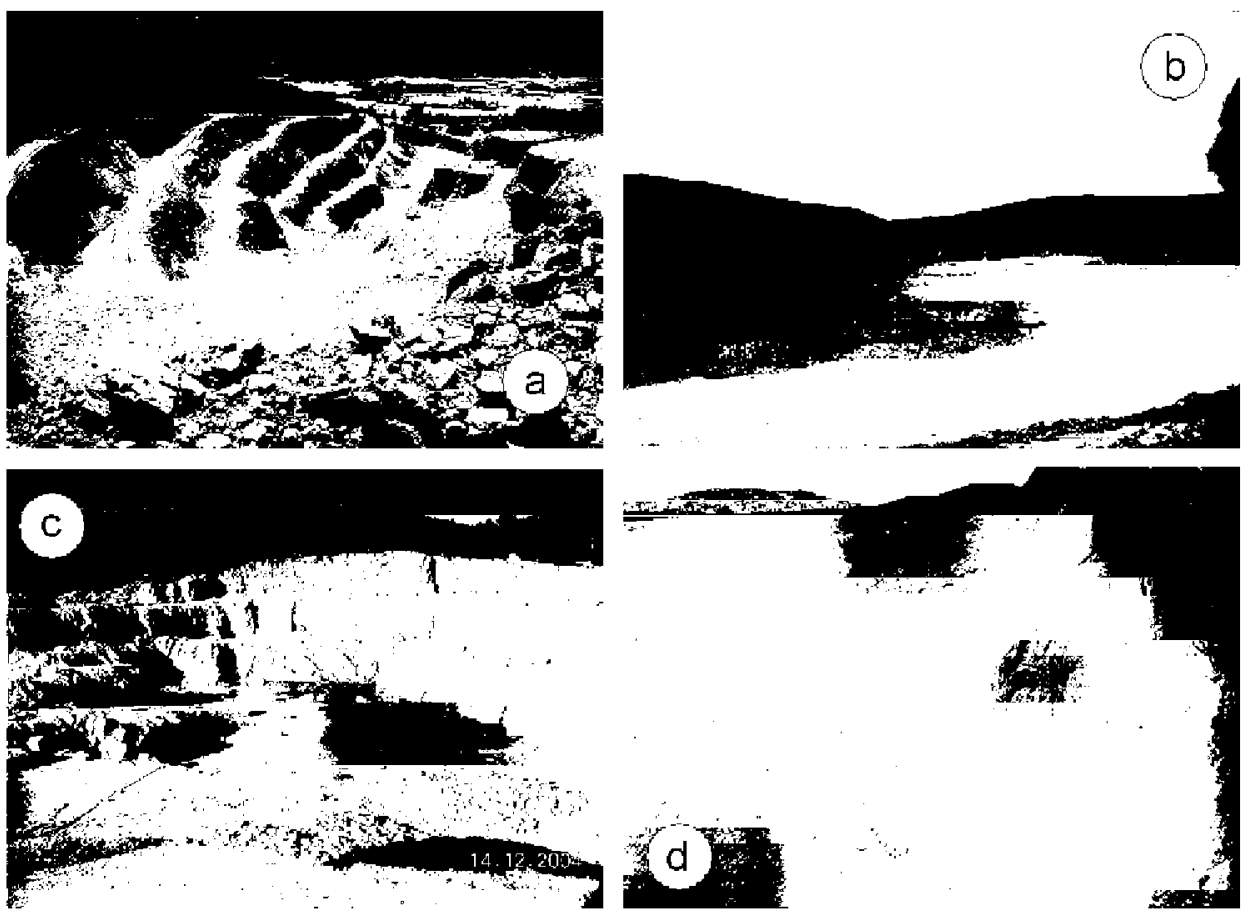

Fig. 15. General views of four of the six quarries evaluated using ROFRAQBASIC, RHRS BASIC $_{\text {and RHRON }}$ BAsIC: (a) aggregate schist quarry OU-01; (b) limestone quarry LU-01; (c) aggregate granodiorite quarry OU-02; (d) slate quarry BI-01.

ROFRAQ ${ }_{\text {BASIC }}-$ RHRS $_{\text {BASIC }}$

(DATA FROM DIFFERENT QUARRIES)

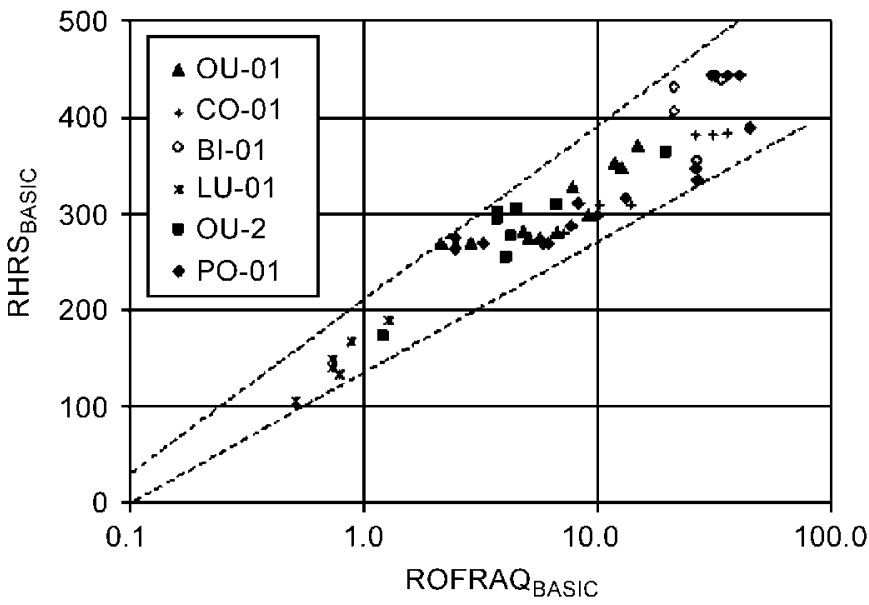

Fig. 16. Results for ROFRAQ ${ }_{B A S I C}$ vs. RHRS $_{\text {BASIC }}$ (all quarries).

(possible due to the multiplicative structure of ROFRAQ) fitted to the points representing the data obtains correlation coefficients that are generally close to $1\left(R^{2}=0.90\right.$ for ROFRAQ $\mathrm{BASIC}$ vs. RHRS $\mathrm{BASIC}_{\mathrm{C}}$ and $R^{2}=0.75$ for ROFRAQ ${ }_{\text {BASIC }}$ vs. RHRON BASIC $_{1}$. This would indicate that the compared parameters represent similar concepts, and so it can be affirmed that ROFRAQ adequately reflects the phenomenon of rockfall in quarry slopes. (Note that a correlation coefficient of 1 cannot logically be expected, as each method emphasises factors that have
ROFRAQ $B A S I C$ vs. RHRS BASIC $_{\text {RESULTS AND }}$ CORRELATION FOR ALL QUARRIES

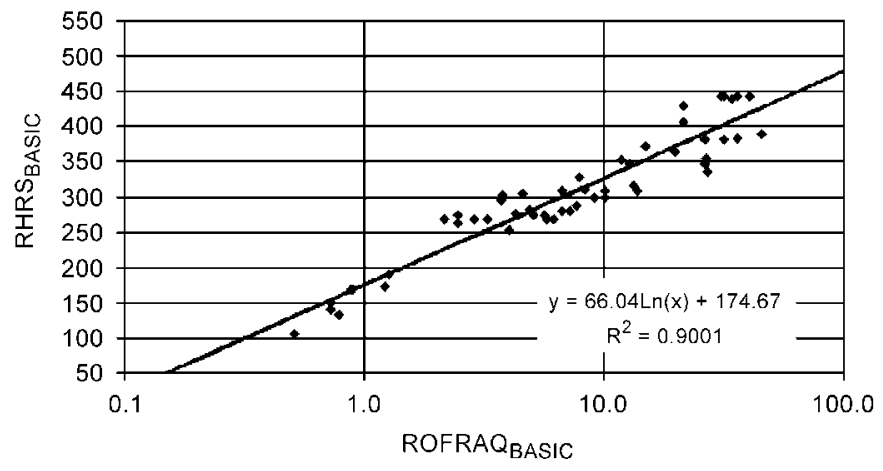

Fig. 17. Results and correlation for ROFRAQBASIC vs. RHRS BASIC (all $_{\text {B }}$ quarries).

been demonstrated to be of greater relevance to the problem analysed.)

Finally, Fig. 19 shows correlation between the two adapted road rockfall methods, RHRS $_{\text {BASIC }}$ and RHRON $_{\text {BASIC. }}$. The level of correlation in this case $-R^{2}=0.82$ is lower than for ROFRAQ ${ }_{\text {BASIC }}$ vs. RHRS $_{\text {BASIC }}$ and higher than for ROFRAQ ${ }_{B A S I C}$ vs. RHRON BASIC. $_{\text {. }}$

Representing an initial validation for the proposed method, these results, in general terms, indicate a satisfactory level of agreement between the proposed method-designed for quarries and open pit mines - and the methods designed specifically for roads, but adapted for comparison purposes. 
ROFRAQ ${ }_{B A S I C}$ vs.RHRON BASIC $_{\text {RESULTS AND }}$

CORRELATION FOR ALL QUARRIES

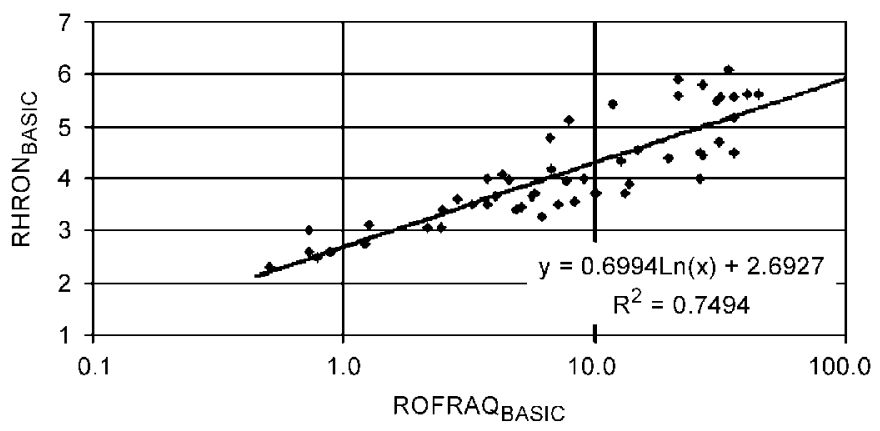

Fig. 18. Results and correlation for ROFRAQ (all quarries).

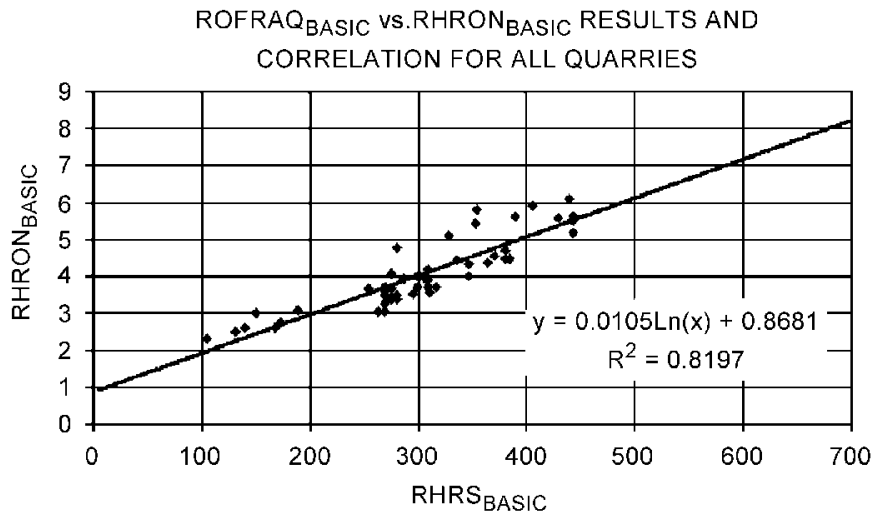

Fig. 19. Results and correlation for RHRS $_{\text {BASIC }}$ vs. RHRON BASIC (all $_{\text {B }}$ quarries).

\section{Conclusions}

In this article, the authors have described an empirical method-Rockfall Risk Assessment for Quarries (ROFRAQ) - designed to assess the risk associated with rockfalls in quarries. The method is probabilistic, in that any accident that occurs will do so as a consequence of a sequence of events. Although the proposed method was developed using data from Galician (NW Spain) rock quarries, it can theoretically be extrapolated to other temperate climate areas. It is important to put forward that since the application of the method has been performed in quarries in temperate climates, the authors do not know whether the method, and particularly rating $C$, could be valid or not for instance in very arid (deserts), wet (tropical lands) or cold (polar regions) zones. They believe that rating $C$ must be remade for every type of broad climate conditions.

A field survey of six different types of quarries was conducted, involving a study of 57 slope faces.

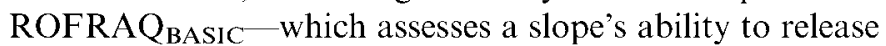
rocks, but disregards the presence of people and machines at a slope's toe-was compared to adapted versions of other rockfall hazard estimators (RHRS and RHRON) for roads. The comparison revealed good correlation, which would indicate that the ROFRAQ approach is reliable. The results obtained would also seem to agree with quarry employee observations for most of the studied slopes. Future analyses of results will guide further fine-tuning and enhancement of the method.

An extension of ROFRAQ to estimations of accident probabilities also produced interesting results and is further evidence that the method works well in general terms. When the estimated accident probability for a standard quarry was extrapolated to registered hard-rock quarries for a province and an entire country (Spain), the result was an accident rate that was equivalent to officially recorded statistics.

As a practical method for assessing rockfall accident risk in quarries, ROFRAQ is a potentially useful as a guideline decision-making tool for quarry managers and staff, mining authorities, and insurance companies, particularly in regard of both maintaining safety standards and detecting particular risks and weaknesses in the mining process, finally reducing accident costs. It should not be considered a precision tool and it can also guide the use of rockfall protection systems

ROFRAQBASIC is also an indicator of the natural trend of slope to release rocks. This information can be used to regulate the risk of a slope face, by exploiting an area only in dry periods, or by developing mining in such a way that only in the final stages of mining, machines work under the hazardous area.

It should be pointed out that the approach is aimed to obtain a preliminary and update view of the evolution of face stability in the quarry: the countermeasures have to be implemented in order to let the workers in safe conditions, eventually by changing some of the quarrying parameters.

As a final comment, it is important to bear in mind that the quantification of data for natural materials such as rock masses is invariably subject to a certain degree of subjectivity and uncertainty. Consequently, ROFRAQ should be used more as a guideline rather than as a precision tool.

\section{Acknowledgements}

The authors thank the Autonomous Government of Galicia (Spain) for financial support for this research project. Ailish M.J. Maher and Piedad García provided assistance with English usage in a version of the manuscript.

\section{References}

Hervas J, editor, Lessons learnt from landslide disasters in Europe. European Commun Joint Research Centre, Institute for the Protection and Security of the Citizen, Technological and Economic Risk Management Unit, 1-21020 Ispra (VA), Italy, 2003, 90pp. 
Hood M, Brown ET. Mining rock mechanics, yesterday, today and tomorrow. In: Proceedings of 9th international congress on rock mechanics, Paris, 1999. p. 1551-76.

Hungr O, Evans SG. Engineering aspects of rockfall hazard in Canada. Geol Surv Canada, Open File 1989;2061:102.

Badger TC, Lowell S. Rockfall control in Washington state. In: Rockfall prediction and control and landslide case histories. Transportation research record, no. 1342. Washington: National Research Council, 1992. p. 14-9.

Rey J. Siniestralidad en las explotaciones mineras de la provincia de Pontevedra. Unpublished paper presented on 1st mining safety meeting, Vigo, Spain, 2000.

Work hazard protection. Evaluation guide for quarries and gravel pits. ANEFA (Spanish Association of Aggregate Producers), 1999.

ANEFA (Spanish Association of Aggregate Producers). Informe sobre los accidentes ocurridos en explotaciones de áridos durante el periodo (1987-1995), Madrid, 2001.

Taboada J, Alejano LR, García-Bastante F, Ordóñez C. Total exploitation of and ornamental granite quarry. Mater Construcción 2005;55(279):67-78

Pierson LA, Davis SA, van Vickle R. Rockfall Hazard Rating System implementation manual. Federal Highway Administration report FHWA-OR-EG-90-01, US Department of Transportation, 1990. Franklin JA, Senior SA. The Ontario Rockfall Hazard Rating System. In: Proceedings of the conference on engineering geology and environment, Athens, 1997. p. 647-58.

Senior SA. Ontario Rockfall Hazard Rating System. Field procedures manual. Report draft, Materials Engineering and Research Office, Ont., 2003. 36pp.

Mazzocola DF, Hudson JA. A comprehensive method of rock mass characterization for indicating natural slope instability. Q J Eng Geol 1996;29:37-56.

Call RD. Slope stability. In: Hartman HL, editor, SME mining engineering handbook. Society of Mining Engineers, 1992. p. 881-96. Ryan TM, Pryor PR. Designing catch benches and interramp slopes. In: Hustrulid WA, McCarter MK, Van Zyl DJA, editors, Slope stability in surface mining. Society of Mining Engineering, 2001. p. $27-39$.

Giani GP. Rock slope stability analysis, 1992. p. 191-208.

Hungr O, Evans SG. Engineering evaluation of fragmental rockfall hazards. In: Proceedings of 5th international symposium on landslides, Lausanne, 1988. p. 685-90.

Bozzolo D, Pamini R, Hutter K. 1988. Rockfall analysis-a mathematical model and its test with field data. In: Proceedings of 5th international symposium on landslides, Lausanne, 1988. p. $555-60$

Fornaro M, Peila P, Nebbia M. Block falls on rock slopes: application of a numerical simulation program to some real cases. In: Proceedings of 6 th international congress IAEG, Amsterdam, 1990. p. 2173-80.

Azzoni A, de Freitas MH. Prediction of rockfall trajectories with the aid of in situ test. Rock Mech Rock Eng 1995;28(2):111-24.

Giani GP, Giacomini A, Migliazza M, Segalini A. Experimental and theoretical studies to improve rockfall analysis and protection work design. Rock Mech Rock Eng 2004;37(5):369-89.

Rocscience Inc. Manual of RocFall, V. 4.0, 2002.

Piteau DR, Clayton R. Computer rockfall model. In: Proceedings of the meeting on rockfall dynamics and protective works effectiveness, Bergamo, Italy, 1976. ISMES Pub. no. 90. p. 123-5.

Agliardi F, Crosta GB. High resolution three-dimensional numerical modeling of rockfalls. Int J Rock Mech Min Sci 2003;40:455-71. Copons Llorens R, Altimir Planes J, Amigó Mitjana J, Vilaplana Fernández JM. Metodología Eurobloc para el estudio y protección de caídas de bloques rocosos. Principado de Andorra. In: Proc V simposio Nacional sobre Taludes y Laderas Inestables, Madrid, 2001. p. $665-75$.

Fookes PG, Sweeney M. Stabilization and control of local rockfalls and degrading slopes. Q J Eng Geol 1976;9:37-55.
Spang RM, Rautenstrauch RW. Empirical and mathematical approaches to rockfall prediction and their practical applications. In: Proceedings of 5 th international symposium on landslides, Lausanne, 1988. p. 1237-43.

Ritchie AM. The evaluation of rockfall and its control. Highway Res Rec 1963;17:13-28.

Pierson LA, Gullixson CF, Chassie RG. Rockfall catchment area design guide. Final report SPR-(032) Metric ed. 2001, Oregon Department of Transport, FHWA. 〈http://www.oregon.gov/ODOT/ TD/TP_RES/docs/Reports/RokfallCatchAreaDesMetric.pdf > [last consulted: 10 December 2005].

Alejano LR, Pons B, Bastante FG, Alonso E, Stockhausen HW. Slope geometry design as a means of rockfall control in quarries. Int $\mathrm{J}$ Rock Mech Min Sci 2007;44:903-21.

Bieniawski ZT. Estimating the strength of rock materials. J S Afr Inst Min Metall 1974;74(8):312-20.

Bieniawski ZT. Rock mass classification in rock engineering. In: Proceedings of the symposium on exploration for rock engineering, Cape Town, 1976. p. 97-106.

Hoek ET. Rock engineering course notes. Chapter 9: Analysis of rockfall hazards. 〈http:/www.rocscience.com/roc/Hoek/Hoeknotes 2000.htm >; 2000 [last consulted: 15 April 2006].

Kliche Ch. Rock slope engineering. Littleton, CO: Society of Mining Engineering, 2000.

Barton N, Lien R, Lund J. Engineering classification of rock masses for the design of a tunnel support. Rock Mech 1974;6(4): 189-236.

Barton N, Grimstad E. The Q system following 20 years of application in NATM support selection. In: Proceedings of 43rd Coll, Salzburg, 1994. p. 428-36.

Alejano LR, Bastante FG, Alonso E, Gómez-Márquez I. Stability analysis and design of two quarry slopes with the help of numerical modeling. In: Proceedings Eurock 2001, Espoo, Finland, 2002. p. $801-6$.

Alejano LR, Alonso E. Application of the shear and tensile strength reduction technique to obtain factors of safety of toppling and footwall rock slopes. In: Proceedings Eurock 2005, Brno, Czech Republic, 2005. p. 7-13.

Brown ET, editor. ISRM Suggested Methods. Oxford: Pergamon; 1981.

Hoek E, Bray JW. Rock slope engineering. third ed. London: Inst Min Metall; 2000.

Hudson JA, Harrison JP. Engineering rock mechanics: an introduction to the principles. London: Pergamon; 1997.

Itasca. Manual of code UDEC 3.0. Minneapolis, 2001.

Stockhausen H, Alejano LR. An empirical method to estimate the risk of accidents due to rock falls in quarries (I): methodology. In: Proceedings of international conference on slope engineering, Hong Kong, 2003. p. 134-9.

Stockhausen H, Alejano LR. An empirical method to estimate the risk of accidents due to rock falls in quarries (II): a case study. In: Proceedings of international conference on slope engineering, Hong Kong, 2003. p. 140-5.

Bunce CM. Risk analysis for rockfall on highways. MSc thesis, Department of Civil Engineering, University of Alberta, 1994.

Palisade. Precision Tree. Decision analysis add-in for Microsoft Excel. Newfield, NY: Palisade Corp.; 2000.

Nielsen ND, Hartford DND, McDonald TF. Selection of tolerable risk criteria for dam safety decision making. In: Proceedings of Canadian dam safety conference, Vancouver, 1994. p. 35569 .

Starfield AM, Cundall PA. Towards a methodology for rock mechanics modelling. Int J Rock Mech Min Sci 1988;25(3): 99-106.

Del Greco O, Oggeri C. Reinforcement design and control of rock slopes above tunnels portals in northern Italy. Int J Rock Mech Min Sci 2004;41(1):786-91. 
Oggeri C, Peila D. Protection of transportation system against rock falls. In: Proceedings of 8 th international symposium on landslides, Cardiff, 2000. p. 1141-6.

Pelizza S, Oggeri C, Oreste P, Peila D. Protection of tunnel portals against rockfall. In: Proceedings of ITA-AITES world tunnel congress, Milano, 2001. p. 579-87.
Peila D, Oggeri C. The use of rockfall protection systems in surface mining activity. Int J Surf Min Recl Environ 2003;17(1):51-6.

Volkkwein A, Melis L, Haller B, Pfeifer R. Protection from landslides and high speed rockfall events-reconstruction of Chapman's Peak Drive. In: Structures and extreme events, IABSE symposium, 2006. p. $314-5$. 